\title{
Green microalgae biomolecule separations and recovery
}

\author{
Chelsea Dixon and Lisa R. Wilken*
}

\begin{abstract}
Microalgae biomass has garnered significant attention as a renewable energy feedstock and alternative to petroleumbased fuels. The diverse metabolism of green microalgae species additionally provides opportunities for recovery of products for feed, food, nutraceutical, cosmetic, and biopharmaceutical industries. Recently, the concept of using microalgae as part of a biorefinery model has been adopted in place of refinery methods focused on recovering one target product. This has led to producers exploring co-production of high value and high volume products in an effort to improve process economics. With numerous potential products and applications, the biomass source or specific strain must be carefully selected to accumulate extractable levels of the target molecule(s). It is additionally imperative to understand the morphology and metabolism of the selected strain to cost-effectively manage all stages of commercial production. This review will focus specifically on microalgae in the division of Chlorophyta, or green algae and their extracellular matrices (ECM), potential for commercial products, and finally describe a holistic approach for biomolecule extraction and recovery. Additionally, cell disruption and fractionation methods for recovery of biomolecules for commercial products are highlighted along with an alternative method, aqueous enzymatic processing for multiple biomolecule extraction and recovery from green microalgae. An emphasis is placed on connecting the morphological characteristics of microalgae ECM or organelle membranes to implications on separation and purification technologies.
\end{abstract}

Keywords: Microalgae, Enzymes, Biorefinery, Downstream processing

\section{Introduction}

Microalgae, a large and diverse group of unicellular photo- and heterotrophic organisms, have significant potential for production of a vast array of valuable products for diverse industries. Microalgae use solar energy, nutrients, and carbon dioxide $\left(\mathrm{CO}_{2}\right)$ to produce proteins, starch, lipids, and other biomolecules. Much research has been conducted in regard to using microalgae biomass as an alternative fuel source, but other valuable products can be sourced from microalgae including bioactive compounds for human health and nutrition (omega-3 fatty acids), biopharmaceutical, cosmetic, and feed industries (Skjånes et al. 2012; Mercer and Armenta 2011). Valueadded products include carotenoids; phycobiliprotein pigments; vitamins $\mathrm{C}, \mathrm{E}$, and biotin; fatty acids (linolenic,

*Correspondence: Iwilken@ksu.edu

Biological and Agricultural Engineering Department, Kansas State University, 1016 Seaton Hall, Manhattan, KS 66506, USA arachidonic, etc.); and recombinant proteins (Converti et al. 2009).

While microalgae has demonstrated potential as an alternative and sustainable biomass source for biofuels and bioproducts, techno-economic assessments have repeatedly concluded that microalgae-derived fuels, animal feed inputs, and bulk chemicals cannot currently compete with market prices (Chauton et al. 2015; Benemann 2013). Central to this barrier to commercialization of microalgal products are the processing techniques used to extract and recover biomolecules. The most critical step to access internally stored biomolecules is cell disruption. Current processes are energy-intensive, expensive, and/or utilize organic solvents, which has significant environmental implications. To improve process economics and promote product commercialization, processes should be robust, energy-efficient, minimize the environmental impact, and maintain product quality. Thus, alternative processing techniques such as 
enzymatic hydrolysis are being explored for cell disruption. Enzymatic hydrolysis, in addition to serving as pretreatment for cell disruption, can be selectively used for extraction of valuable biomolecules produced in organelles. By employing a strategy whereby algal species are classified based on ECM characteristics, enzymes specifically targeting components found in the ECM can be used to permeabilize and/or lyse the matrix prior to additional processing. Additionally, identifying structural components of organelle membranes can similarly allow for targeted enzymatic hydrolysis of organelles and facilitate extraction of biomolecules. This paper discusses traditional and emerging products and general downstream processing (DSP) of green microalgae and reviews the cell morphology of several microalgae species including Dunaliella, Haematococcus, Nannochloropsis, Spirulina, Chlorella, and Chlamydomonas through classification of their ECM. Additionally, cell disruption and fractionation methods for recovery of biomolecules are discussed along with an alternative processing strategy for multiple biomolecule extraction and recovery from microalgae.

\section{Products and downstream processing Commercial products}

The first unialgal cultures (Chlorella vulgaris) were produced in 1890. After 1948, concurrent research efforts into new applications of algal cultures occurred in the United States, Japan, and Germany with a primary focus on algae use for food production (Burlew 1953). This research ultimately spurred the first industrial-scale production of Chlorella biomass in Japan in the 1960s. Dried whole cells were supplied to research institutes to develop nutritional and medical applications and mass cultivation techniques, which led to the Chlorella health food industry known today (Borowitzka 2013). This was followed by Spirulina production in Mexico in the 1970s and Dunaliella salina production in Australia in the mid-1980s (Milledge 2010). In the 1980s and 1990s, the US Department of Energy funded the Aquatic Species Program with a goal of producing oil and ultimately biofuels from microalgae. The program funding was ultimately cut due to budgetary pressures, but the foundation for generating cost-effective and scalable processing of microalgae into biofuels was set. Although microalgae from biofuels continues to be a primary goal for the research community, other microalgae-derived bioproducts have been commercially developed. Currently, the microalgae product market includes bioactive compounds from a variety of different green microalgae. Genera most commonly used for commercial production include Dunaliella, Haematococcus, Nannochloropsis, Chlorella, and Chlamydomonas. Additionally, the cyanobacterium or blue-green algae Spirulina is used for commercial products. The unique metabolisms of selected green microalgae species have been exploited for the production of $\beta$-carotene using Dunaliella, astaxanthin using Haematococcus pluvialis, Eicosapentaenoic acid (EPA) from Nannochloropsis species, components of animal feed formulation from Spirulina, human health products from Chlorella species, and cosmetics and biofuel feedstock sourced from multiple green microalgae species. In many instances, the aforementioned microalgae species are manipulated during the cultivation stage to redirect their metabolisms toward production or accumulation of valuable products at the expense of diminished cell growth.

\section{$\beta$-Carotene from Dunaliella}

$\beta$-Carotene is a provitamin A carotenoid with success as a natural food pigment, coloring agent, or health food (Markou and Nerantzis 2013) and has additionally been recognized for its antioxidant properties and role as an essential nutrient (Singh et al. 2016). The carotenoid is non-polar; lipophilic; insoluble in water, acids, and alkalis; but soluble in benzene, chloroform, and carbon disulfide. The halotolerant microalgae, Dunaliella salina, is used for the commercial production of $8.5-30 \%$ of the global $\beta$-carotene supply per year (Ericksen 2016).

By the year 2018, the global market for $\beta$-carotene is expected to be US\$334 million (BCC Research 2011). Global producers include companies in Australia, Israel, India, and China. $\beta$-Carotene can comprise up to $14 \%$ dry weight of $D$. salina and accumulates within lipid globules in the chloroplast interthylakoid space (Markou and Nerantzis 2013; Shariati and Hadi 2011) under stress parameters including high salinity, high temperature, high light, and nutrient limitation (Haghjou and Shariati 2007; Nguyen et al. 2016). Since $\beta$-carotene accumulates under suboptimal growth conditions, manufacturers must establish a balance between biomass production and product accumulation. Biomass production can be "intensive" in which all cultivation factors are controlled to affect cell growth and chemistry or "extensive" in which growth is slowed down via cultivation in a brine solution to promote $\beta$-carotene accumulation (Raja et al. 2007). Extensive production occurs in large unstirred outdoor ponds while intensive production occurs in paddle wheel stirred raceway ponds (Borowitzka 1990). Harvesting and dewatering strategies for D. salina are complicated by the lack of a protective cell wall and natural buoyancy. Successful lab- and pilot-scale strategies for harvesting include high $\mathrm{pH}$-induced flocculationflotation and membrane filtration (Besson and Guiraud 2013; Monte et al. 2018). Extraction of $\beta$-carotene commercially can occur via traditional solvent extraction, but concerns about toxicity and residuals limit market 
acceptance. Patented, commercial extraction methods include supercritical $\mathrm{CO}_{2}$, biomass saponification followed by solvent extraction, or hot oil extraction (Borowitzka and Borowitzka 1990). Other extraction methods include edible oil (vegetable oil) extraction, microwaveassisted extraction, ultrasound-assisted extraction (Kyriakopoulou et al. 2015), and "milking" D. salina in closed photobioreactors (PBR) with the addition of an organic phase (dodecane) (Kleinegris et al. 2009).

\section{Astaxanthin from Haematococcus pluvialis}

Astaxanthin is a carotenoid used as a natural pigment source for aquaculture with antioxidant activities and human health implications in skin cancer pathogenesis, coronary heart disease, and infection resistance (Yaakob et al. 2014). The global astaxanthin market is predicted to be US $\$ 1.1$ billion by 2020 (Industry Experts 2015). Haematococcus pluvialis is used to produce 280 metric tons of astaxanthin annually which accounts for $<1 \%$ of the global market with the remaining astaxanthin sourced from other marine life, Phaffia yeast, Paracoccus bacteria, or chemical synthesis (Panis and Carreon 2016). Astaxanthin is polar, lipophilic, and soluble in acetone, acetic acid, chloroform, pyridine, and dimethyl sulfoxide (DMSO) (with heat application) (Kim et al. 2008).

Commercially, Haematococcus pluvialis is grown in indoor and outdoor PBR or hybrid pond-PBR systems to control contamination. Typically, a two-step cultivation process is used including accumulation of vegetative cells in optimal growth conditions followed by exposure to suboptimal environmental or nutrient stresses (Sarada et al. 2002). During stress conditions, vegetative cells become hematocysts and accumulate astaxanthin to 1.53.0\% dry weight (Shah et al. 2016). The cells are then harvested via settling and centrifugation, disrupted rapidly with homogenization or ultrasonication to retain astaxanthin integrity, and cracked or pulverized to enhance extraction and recovery.

\section{Biofuels}

The high lipid and carbohydrate content of green microalgae confers the possibility of conversion to biofuels (Sahay and Braganza 2016) including biodiesel, bioethanol, biomethane, and bio-oil (Lam and Lee 2012). Chlorella vulgaris and Nannochloropsis oculata have been successfully used for the production of biodiesel while Chlorella, Dunaliella, Chlamydomonas, Scenedesmus, and Spirulina sp. are all considered good candidates for bioethanol production. Additionally, Chlorella and Chlamydomonas sp. can be used for biogas production. Production begins with accumulation of lipid-rich algal biomass and is followed by harvesting, dewatering, lipids/sugar extraction and conversion, and additional processing of biomass for valuable co-products (Sing et al. 2013). Flocculation and subsequent flotation are commonly used for harvesting microalgae for biofuels because this technique can handle the diversity in shape, size, specific weight, and surface charge of various microalgae cells. Following harvesting and dewatering, microalgae are subject to cell disruption or pretreatment strategies. Cells can be mechanically pressed for access to lipid precursors of biodiesel or bio-oil or enzymatically hydrolyzed for access to fermentable sugars for bioethanol. Lipids are extracted with conventional solvents, green solvents, subcritical water, supercritical $\mathrm{CO}_{2}$, or co-solvent mixtures (ionic liquids/polar covalent molecules) (Sing et al. 2013). Lipids are converted to biodiesel via transesterification, pyrolysis, or hydrogenation. Enzymatic saccharification hydrolyzes carbohydrates into simple sugars that are then fermented to bioethanol (Hernández et al. 2015). Hydrothermal liquefaction is used to produce bio-oil from microalgae in an aqueous conversion environment with no prior drying (Guo et al. 2015). Microalgae biofuels are advantageous due to the high oil content of various species and the cultivation time. Additionally, one species can be used for multiple fuels (i.e., biodiesel produced from lipids and bioethanol production from lipid-depleted residual biomass) (Gutiérrez-Arriaga et al. 2014). Challenges for widespread commercialization of microalgae biofuels include the diversity in size and morphology of lipid-producing algae strains, harvest of dilute algae suspensions, and translation of laboratory- and pilot-scale techniques for commercial operations. Additionally, harvesting and dewatering operations greatly impact economically feasibility (Wu et al. 2012).

\section{Eicosapentaenoic acid (EPA) from Nannochloropsis}

Eicosapentaenoic acid (EPA) is a marine-derived omega-3 fatty acid and essential fat with various human health applications (Swanson et al. 2012). The 2016 global market for omega-3 products is US\$34.7 billion (Packaged Facts 2012). The current source of EPA is mainly fish oil, but Nannochloropsis species are promising alternative producers (Chauton et al. 2015) as they can produce EPA to levels of $1.1-12 \%$ dry weight depending on culturing conditions (Ma et al. 2016; Camacho-Rodríguez et al. 2013; Chen et al. 2013a, b). On a commercial scale, Nannochloropsis sp. are cultivated photoautotrophically using natural light and carbon dioxide from power plants or flue gas in raceway ponds. The microalgae can additionally be grown heterotrophically and mixotrophically, but on a smaller bench- or pilot-scale. Following culturing, algae cells are separated from media via filtration, flocculation, or centrifugation and then dried. EPA is extracted via solvent (hexane), refined by degumming, bleaching, 
or deodorization, and encapsulated (Adarme-Vega et al. 2012).

\section{Animal feed formulation with Spirulina}

As an edible microalgae, Spirulina is not only a human food supplement, but also valuable as an animal feed formulation component due to its high protein (60-70\% dry weight), vitamin, and mineral contents (Harun et al. 2010). Global production as of 2010 was 5000 metric ton/ year (Norsker et al. 2011) with producers in the United States, China, India, and Chile. Commercial production occurs in shallow raceway ponds mixed by a paddle wheel (Belay 2013) in high saline and alkaline conditions and the biomass is then harvested and processed for inclusion in animal feed formulations (Yaakob et al. 2014). Harvesting and processing include filtration, concentration, neutralization, grinding/homogenization, and dehydration. Drying methods include drum drying, spray drying, sun drying, solar drying, cross-flow air drying, vacuum-shelf drying, and freeze drying (Belay 2013). Typically, Spirulina is neutralized with an acidic solution and dried or dehydrated as this allows for easy integration into animal feed formulations (Ahsan et al. 2008).

\section{Human health products from Chlorella}

The high content of bioactive compounds in Chlorella makes it an attractive source as a nutritional food and human health product with global production in excess of 2000 metric tons/year (Ramaraj et al. 2016). In particular, the carbohydrate and protein contents have led to the production of nutraceutical tablets, teas, and noodles among other products (Liu and Chen 2014). The majority of commercial Chlorella production is done using mixotrophic mass cultivation (Hudek et al. 2014) in PBR with various geometries. A small percentage of industrial Chlorella cultivation occurs heterotrophically in fermenters but high operating costs limit widespread commercial use. Various harvesting strategies such as flocculation, flotation, filtration, gravity sedimentation, and centrifugation (Liu and Chen 2014) are employed on a commercial scale. To access carbohydrates, mostly contained within the cell wall, a disruption technique must be employed. Commercially, this can include high pressure homogenization, enzymatic lysis, bead milling, or grinding (Huang et al. 2016). When sold as a health food, dried Chlorella biomass is most commonly pulverized or spray dried and supplied in tablet or capsule form for consumption.

\section{Cosmetics}

Several species of microalgae have been used for skin and hair care products including Spirulina, Chlorella, Dunaliella, and Nannochloropsis extracts. More specifically, carotenoids such as astaxanthin, $\beta$-carotene, and lutein can be included as part of topical cosmetic products for protection against hyper-pigmentation or UV-induced damage (Wang et al. 2015; Mourelle et al. 2017). Similarly, polysaccharides from various green microalgae species can be included in cosmetic products for the purposes of antioxidant activity, gelling, or thickening (Mourelle et al. 2017). Due to the application of these products on the skin of consumers, consistent quality and controlled growth environments are necessary for the microalgae bioproduct precursors. The microalgae are grown in PBR with optimal light and nutrients which leads to consistent accumulation of the bioactive substances for skin care products. For whole cell products, biomass is centrifuged or filtered to separate cells from growth media. The biomass is then lyophilized, spray dried, of flash dried to produce cake, flakes, powder, or flour (Brooks and Franklin 2009). When intracellular products are of interest, whole cells are disrupted via high pressure homogenization or ultrasonication (Coragliotti et al. 2010). The lysate is then centrifuged or filtered prior to lyophilization or drying with heat. Polysaccharides and proteins can be recovered with precipitation or tangential flow filtration (Coragliotti et al. 2010) while oil is typically recovered with solvents or supercritical $\mathrm{CO}_{2}$ (Brooks and Franklin 2009). The final products or extracts are often decolorized by bleach, solvents, activated carbon, high salt solutions, or enzymes and then incorporated into cosmetic products (Coragliotti et al. 2010).

\section{Emerging products}

While the aforementioned products have well established pilot and/or commercial production streams, there are emerging opportunities to additionally capitalize on green microalgae metabolic diversity. Research is currently being conducted in using the microalgal platform for recombinant protein expression and accumulation (Rasala and Mayfield 2015), bioplastics/biopolymers (Wang 2014), and bioremediation (Ummalyma et al. 2018). Research advancements have been made but a better understanding of the cellular processes and their response to environmental stimuli are critical for commercialization.

\section{Recombinant proteins}

Recombinant proteins (RP) such as antibodies, immunotoxins, subunit vaccines, and industrial enzymes have been expressed in microalgae (Rasala and Mayfield 2015; Scranton et al. 2015; Hempel and Maier 2016; Yusibov et al. 2016). Chlamydomonas, Chlorella, and Dunaliella sp. are generally regarded as safe organisms and can be potentially used for RP production, but most studies have focused on Chlamydomonas reinhardtii. 
Completed sequences for the nuclear, chloroplast, and mitochondrial genomes have allowed for the establishment of transformation methods and the introduction of recombinant molecules into $C$. reinhardtii. The expression level of most RP in C. reinhardtii ranges from 0.1 to $5 \%$ of total soluble protein (TSP) but can be as high as $20 \%$ TSP. Expression in the nucleus or chloroplast is most common with the chloroplast having distinct advantages including the possibility of targeted DNA integration, disulfide bond formation, the absence of gene silencing mechanisms, and high level of expression (GuzmánZapata et al. 2016; Scaife et al. 2015; Rasala and Mayfield 2011). Nuclear expression, while allowing RP secretion and glycosylation, suffers from lower accumulation levels, transgene silencing, and positional effects (Rasala and Mayfield 2015; Scranton et al. 2015).

The first antibody expressed was a large single-chain antibody against Herpes simplex virus glycoprotein D in 2003 (Rasala and Mayfield 2015). Complete human Immunoglobulin G (IgG) antibody against anthrax has also been expressed and more recently, mono and dimeric single-chain immunotoxins were expressed in the Chlamydomonas chloroplast (Tran et al. 2012). Other $\mathrm{RP}$ expressed in the Chlamydomonas chloroplast include the E2 protein, an antigen for vaccines against classical swine fever virus (CSFV), at levels of $1.5-2 \%$ TSP, Viral Protein 1-Cholera toxin B (VP1-CTB) vaccine against foot and mouth disease virus at levels up to 3\% TSP (Yan et al. 2016), and oncoproteins and antigens for cancer treatment/prevention (Demurtas et al. 2013).

Various processing steps have been utilized for the extraction and purification of recombinant proteins from C. reinhardtii. For therapeutic applications, RP are subject to additional processing and purity requirements. Thus, the effects of all downstream processing strategies must be closely monitored and optimized to retain the RP integrity and activity. Munjal et al. (2015) reported the pretreatment of cells expressing a single-chain antibody fragment $(\alpha \mathrm{CD} 22 \mathrm{scFv})$ in the chloroplast with ultrasonication followed by reduction of chlorophyll and precipitation of host cell proteins from cell lysates with chitosan (Munjal et al. 2015). The $\alpha \mathrm{CD} 22 \mathrm{scFv}$ was then purified from clarified extraction using capture chromatography. Cells expressing Plasmodium falciparum surface protein 25 (Pfs25TBV/Pfs25), a subunit vaccine candidate for malaria, were likewise pretreated with ultrasonication with purification from clarified extract using affinity chromatography (Munjal et al. 2014).

While RP expression in other green microalgae has not been as thoroughly explored as in Chlamydomonas reinhardtii, Chlorella ellipsoidea has successfully expressed therapeutic recombinant proteins including mature rabbit neutrophil peptide 1 (NP-1) for innate immune system defense and flounder growth hormone for aquaculture (Rasala and Mayfield 2015). Similarly, Dunaliella tertiolecta has expressed industrially applicable bioactive xylanases, $\alpha$-galactosidases, and phytases (Rasala and Mayfield 2015; Yan et al. 2016). Dunaliella salina has similarly been used to express hepatitis B virus surface antigen (HBsAg) to $1.6-3.1 \mathrm{ng} / \mathrm{mg}$ of total protein (Yan et al. 2016). Although these examples of successful expression prove microalgae to be a viable option for RP production, improvements in integrated process development providing high yields and protein stability are critical for commercialization.

\section{Bioplastics/biopolymers}

Bioplastics are biodegradable plastics from renewable biomass sources with a global market value expected to be US $\$ 10$ billion by 2020 (Oilgae 2016). Microalgaederived bioplastics are a combination of microalgae biomass and polymers/additives that are molded or extruded into their final form (articles, sheets, and films). Bioplastics from microalgae are used in the packaging, catering, gardening, medical, and automotive industries (Rajendran et al. 2012) and can be classified as hybridbased plastics, cellulose-based plastics, polylactic acid, or biopolyethylene (Beetul et al. 2016). Spirulina and Chlorella are commonly used for bioplastic production based on their small cell size and protein composition that allows for conversion to bioplastics without prior treatment (Zeller et al. 2013). Microalgae biomass and proteins are converted into bioplastics through a process of denaturation/digestion/fermentation, plasticization, blending, and compatibilization (Wang 2014). Plasticization improves flexibility and durability through the addition of non-volatile, organic molecules such as glycerol, sorbitol, saccharose, urea, triethylene glycol, or polyethylene glycol. Blending mixes compatible polymers such as polyethylene or poly(vinyl alcohol) to the plasticized biomass and compatibilization stabilizes the blended polymers by modifying their interfacial properties. After compatibilization, the bioplastics are molded or extruded with heat and pressure. Microalgae-derived bioplastics have relatively simple production procedures and unlike soy or other common feedstocks for bioplastics, use of microalgae has less impact on food supply (Wang 2014). For commercial viability, the functional properties of microalgae proteins must be improved and methods for removing odor-causing volatiles must be developed (Wang 2014).

\section{Future trends for microalgae products}

For microalgae to extend beyond traditional markets, a concerted effort to diversify products is necessary. Microalgae production companies seek to reach new 
industries such as green chemicals, polymers/plastics, and therapeutics. A biorefinery model is increasingly employed whereby biomass is converted into products for different industries to maximize biomass utilization and minimize residual waste (Zhu 2015). In addition, microalgae producers are exploring co-production of high value and high volume products in an effort to improve process economics (Barbosa and Wijffels 2015) and increase product range.

Life cycle assessment studies have previously concluded that producing algal biomass with the sole intent of using the accumulated lipids (or starch) for biofuel production is not environmentally (Gnansounou and Raman 2016) or economically (Soratana et al. 2014) advantageous. Thus, production and recovery of higher value products like fine chemicals, carotenoids, and therapeutic recombinant proteins along with lipids can promote commercialization. To improve product (target biomolecule) accumulation, candidate algae strains have been genetically manipulated (Singh et al. 2016). With the accumulation of multiple products, producers will need to incorporate methods for assessing the effects of manipulating microalgae metabolism on cultivation strategies. Thus, cultivation and harvesting methods have been studied and optimized while many techniques for extraction and recovery have been developed at benchand pilot-scale. Additionally, alternative extraction techniques such as enzymatic hydrolysis are being explored for translation into industrial-scale processing.

\section{Processing operations for microalgae products Unit operations}

Microalgae have been demonstrated as a source of biomolecules for pigments/dyes, feed, biofuels, cosmetics, nutraceuticals, and even therapeutic molecules, but complex biological structure and costly processing requirements limit industrial-scale production and distribution of products. The DSP of microalgae for valuable bioproducts includes generally includes four major stages: (1) cell disruption/pretreatment; (2) extraction; (3) fractionation, purification, and/or biochemical conversion; and (4) final formulation. Figure 1 illustrates the potential techniques employed at each DSP stage for recovery of common biomolecules (proteins, carbohydrates, lipids, and pigments) from microalgae. Cell morphology and properties of target molecules determine which techniques and methods can be employed at for each of these DSP stages.

Cultivation is the production and accumulation of biomass containing target molecules using a combination of nutrient media, light, mixing/aeration, and $\mathrm{CO}_{2}$ to promote microalgae growth. Commercially, green microalgae can be cultivated in open raceway ponds, photobioreactors, or hybrid systems. Open raceway ponds are cost-effective but prone to contamination, low biomass productivity, and low utilization of $\mathrm{CO}_{2}$ due to constant evaporation (Tan et al. 2018). The ponds are also subject to limited light penetration due to dark zones and inadequate mixing. Photobioreactors allow for bulk quantity microalgae production, are less prone to contamination, and require less land for cultivation. Conversely, photobioreactors are much more costly, difficult to clean, and can experience a buildup of dissolved oxygen (Narala et al. 2016; Tan et al. 2018). Cultivation can also occur with a combination or hybrid blend of open raceway ponds and photobioreactors that can reduce cost and improve productivity. With hybrid cultivation strategies, a dense inoculum is produced in photobioreactors with minimized risk for contamination and then introduced in raceway ponds for continued cultivation and biomass production (Tan et al. 2018). Hybrid cultivation is an interesting strategy for species that accumulate products in nutrient deficient or deplete conditions as photobioreactors can be used for vegetative growth and raceway ponds can be used for bioproduct accumulation (Narala et al. 2016).

Harvesting includes solid-liquid separation by centrifugation, filtration, or gravity sedimentation (Barros et al. 2015) and due to the high volume of algal cultures being processed, this step is often considered to be a processing bottleneck. In fact, harvesting combined with dewatering can account for $20-30 \%$ of biomass production costs (Zhu 2015). To enhance harvesting efficiency via solid-liquid separation, cells can be flocculated by chemical, electroflocculation, and bioflocculation techniques (Chen et al. 2015). For chemical flocculation, salts (e.g., aluminum sulfate and poly aluminum chloride) or polymers (e.g., polyacrylamide and chitosan) are added to change the surface charge of microalgae (Wan et al. 2015). Electroflocculation also modifies surface charge, but the process generates metal ions via a metal electrode instead of metal salts (Pearsall et al. 2011). Bioflocculants are derived from bacteria, fungi, or the microalgae itself (self-flocculation). In this case, the microorganism can be added to the microalgae culture or co-cultured with the microalgae. The flocculants associate with the microalgae cell surface resulting in mixed microalgae-microorganism flocs that can be harvested (Vandamme 2013).

Secondary dewatering by centrifugation or filtration is often performed to minimize the processing volume, concentrate the algal slurry, and drastically reduce the water content (Barros et al. 2015). Concentrated biomass slurry is then dried either by air, solar, spray, rotary, or incinerator drying (Shiratake et al. 2013; Jegathese and Farid 2014; Show et al. 2015).

Microalgae cell disruption methods can be mechanical or non-mechanical (thermal, chemical, biological) 


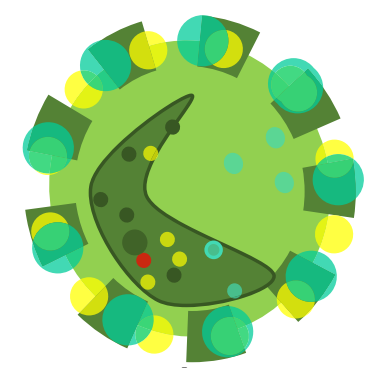

\section{Cell Disruption/Pretreatment}
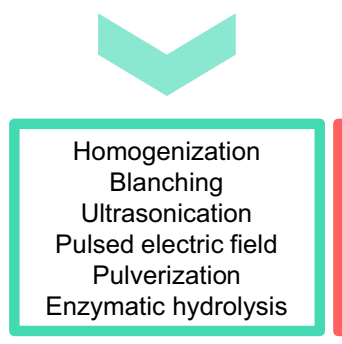
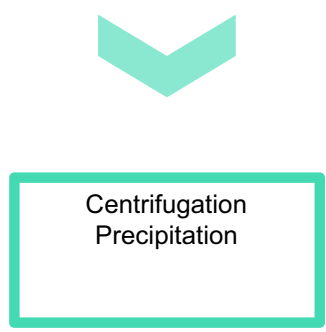

\section{Proteins Carbohydrates}
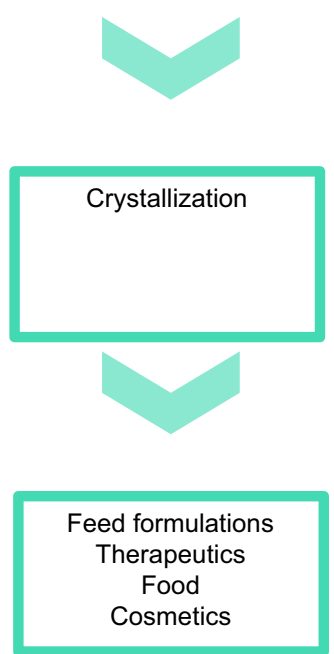
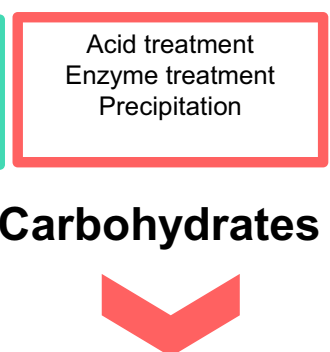
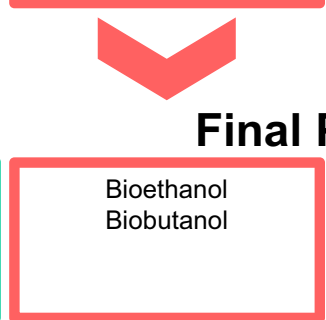

Acid treatment Ultrasonication Enzymatic hydrolysis Ionic liquids

Acetone+boiling ethanol

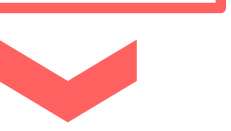

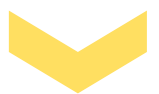

Bead milling Drying

Ultrasonication

Microwave treatment

Biodiesel co-solvent

\section{Extraction}

Solvents (organic, switchable polarity)

\section{Additional Processing}

Lipids

Conversion to fatty acid methyl ester via transesterification

Fermentation with microorganisms

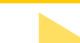

\section{Final Products}

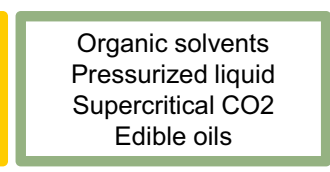

Pigments
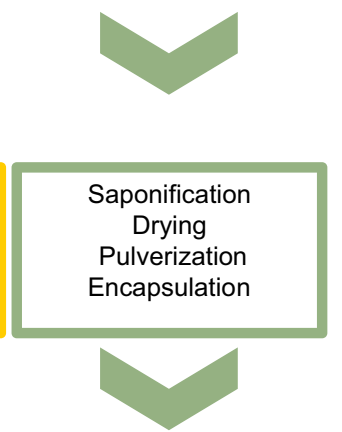

Drying

Pulverization Encapsulation

Feed formulations Cosmetics Nutraceuticals

Fig. 1 Downstream processing steps for the recovery of proteins, carbohydrates, lipids, and pigments

depending on the characteristics of the microalgae cell wall/membrane and target molecules. Mechanical cell disruption methods include bead beating, high pressure homogenization $(\mathrm{HPH})$, high speed homogenization $(\mathrm{HSH})$, ultrasonication, and pulsed electric field (PEF) treatment. Thermal cell disruption can occur via microwave treatment, autoclaving, or freezing. Chemical cell disruption methods include organic solvent treatment, osmotic shock, and acid-alkali reactions. Biological cell disruption occurs by microbial degradation or enzymatic 
hydrolysis. See Green Microalgae "Extracellular matrices and pretreatment strategies for disruption" section for more information on each of these disruption techniques.

After cell walls and membranes have been thoroughly disrupted, extraction and recovery of target products or molecules is the next DSP step. Existing downstream processing operations are primarily designed for the extraction and recovery of one target molecule (proteins, lipids, carbohydrates, pigments, etc.). Soluble protein extraction after cell disruption consists of lysate conditioning ( $\mathrm{pH}$ and/or conductivity adjustment), centrifugation of cell lysate, and recovery of supernatant. Lipid extraction involves mechanical pressing, homogenization, milling, and lipophilic solvent extraction (Cuellar-Bermudez et al. 2014). Prior cell drying or cell disruption is necessary for current industrial-scale extractions because unruptured cells do not permit solvent access to the internally stored lipids. Carbohydrate extraction requires an enzymatic or acidic pretreatment while pigment extraction occurs via conventional solvents, supercritical fluids, or pressurized liquids (Nobre et al. 2013).

After extraction, clarification, capture/purification, and any necessary polishing steps are performed to obtain the final product. For clarification, crude extracts can be filtered or centrifuged to separate debris from any soluble products into the supernatant fraction. Capture and purification occurs mostly for protein products used for human therapeutic, cosmetic, or nutraceutical purposes (Milne 2017). Chromatographic operations and/or precipitation steps are commonly used to purify and concentrate proteins.

For carbohydrates and lipids, conversion is necessary. Carbohydrates are converted to simple sugars via saccharification followed by fermentation into various biofuels such as bioethanol and biobutanol (Hernández et al. 2015). Likewise, lipids undergo transesterification to form biodiesel and byproducts (Zhu et al. 2017). Byproducts are separated from biodiesel by taking advantage of density differences or via distillation processes (Zhang et al. 2016).

\section{Economic considerations}

Economic evaluation of bioproduct production in microalgae has centered largely on microalgae-derived biofuels with much attention given to the cultivation and harvesting operations (Gerardo et al. 2015; Ríos et al. 2013; Beal et al. 2015). The overwhelming hurdle identified to widespread commercial production of microalgae as a bio-feedstock is the cultivation and harvesting strategy employed (Barsanti and Gualtieri 2018; Chia et al. 2018; Beal et al. 2015). It has been repeatedly concluded that cultivation in photobioreactors is more costly than open raceway ponds in terms of capital investment, but when downstream processing costs are considered, the higher cell densities achievable in photobioreactors are more economically advantageous (Davis et al. 2011). Harvesting and dewatering are time and energy-intensive steps and can account for anywhere between 10 and $50 \%$ of total operating costs due to the dilute nature of algae suspensions and large process volume (Barsanti and Gualtieri 2018; t'Lam et al. 2018; Ríos et al. 2013). Operations including microfiltration and centrifugation have been found to cost almost twice that of $\mathrm{pH}$ or gravity sedimentation (Ríos et al. 2013). The economics of subsequent DSP steps including cell disruption, extraction, and purification are not readily reported in literature but identified bottlenecks include overall sustainability related to energy costs and environmental impacts (Barsanti and Gualtieri 2018).

As much of the literature regarding economic evaluation of microalgae production schemes has reported on biofuels, there is a consensus that high value co-products have the potential to increase the total value of microalgae biomass ( $t$ 'Lam et al. 2018). While a complete microalgae biorefinery process is not yet possible, there have been production facilities attempting to integrate a biorefinery concept into their business model whereby multiple high value compounds are produced in lower volumes rather than using microalgae solely for biofuel production (Barsanti and Gualtieri 2018). In order for the biorefinery concept to be a profitable enterprise, simple and effective alternatives to the traditional process operations much be employed. As the research into these alternatives is currently occurring in academia and industry, the field as a whole would benefit from economic modeling and evaluation of downstream processing operations and sensitivity analyses to readily assess potential commercial utility of novel approaches to cell disruption and extraction of multiple bioproducts. While downstream processing includes steps such as harvesting, dewatering or drying, cell disruption, extraction, fractionation, and purification, properties (cell morphology, product localization, and physiochemistry) of the target biomolecule must be considered. Thus, understanding the cell structure and any potential interaction between target molecule and processing equipment and materials is imperative for commercial scale operations.

\section{Extracellular matrices and pretreatment strategies for disruption}

The first step for recovery of biomolecules from within the cell is disruption of the extracellular matrix (ECM). The extracellular matrices of cells serve to protect and defend the microalgae cell, are involved in growth and development, and promote adhesion and interaction with other cells and substrates (Domozych et al. 2012). As a 
structural barrier to release of intracellular molecules, understanding the ECM is imperative for biomolecule extraction and recovery. The following sections begin with a description of the morphology and composition of ECM in various green microalgae species and then highlight traditional techniques for ECM disruption. Finally the emergent use of enzymatic hydrolysis for ECM disruption is discussed with an emphasis on applicable enzyme classes based on ECM composition.

\section{The diversity of extracellular matrices}

Within green microalgae, there exists a wide variety of extracellular matrices (Domozych et al. 2012). The major cell wall polymers found in the matrices include cellulose, hemicelluloses (xyloglucan, mannans, glucuronan, $(1 \rightarrow 3)$ - $\beta$-glucan), and ulvans (Popper et al. 2011). For the six green microalgae discussed in this review, the major ECM groups include cell wall less/deficient species, cellulose-containing (fibrillary) cell-walled species, and multilayered or stratified cell-walled species. Some green microalgae exhibit attributes of several ECM groups such as having a multilayer fibrillary cell wall.

Cell wall less green microalgae include $D$. salina, which lacks a rigid cell wall and is enclosed by a thin plasma membrane. This membrane consists of a glycocalyx-like coating and, therefore, Dunaliella is susceptible to osmolar changes in the environment and exhibit flexible cell morphology (Polle et al. 2017).

Multilayered or stratified cell wall green microalgae include Chlamydomonas reinhardtii, Chlorella, and Spirulina sp. The cell wall of C. reinhardtii is a cellulose-deficient structure that is primarily composed of carbohydrates, proteins, and hydroxyproline-rich glycoproteins (Imam and Snell 1988). Originally thought to be composed of seven layers, further research confirmed five layers within the cell wall (Goodenough 1985). The innermost layer is a loose network of fibers that extends into the "central triplet" layers composed of two fibrous layers and a granular layer. Finally, the outermost layer is composed of anastomosing (connected tubular structures) fiber. The cell wall within the Chlorella species can vary quite drastically. Species can have a single microfibrillar layer or two possess two layers, one microfibrillar and the other mono- or trilaminar (Gerken et al. 2013). The Chlorella trilaminar layer or sheath is composed of sporopollenin as the outermost layer, a secondary wall composed of mannose and chitin-like polysaccharides, and finally an innermost phospholipid bilayer (Kim et al. 2016). Reported polysaccharide composition in C. vulgaris include rhamnose (45-54\%), arabinose (2-9\%), xylose $(7-19 \%)$, mannose $(2-7 \%)$, galactose (14-26\%), and glucose (1-4\%) (Safi et al. 2014a). Spirulina sp. cell walls are composed of four longitudinal layers LI-LIV. LI is not digestible by humans due to the presence of $\beta-1,2$ glucan while LII is composed of proteins and lipopolysaccharides, which allows for easy digestion of Spirulina by humans (Ali and Saleh 2012). LII is additionally made of peptidoglycans which provides some rigidity, but overall the overall cell wall is relatively weak (Apogee Spirulina 2012). LIII is thought to contain protein fibrils and LIV has a structure similar to that of a gram-negative bacteria cell wall (Ciferri 1983). The walls are reportedly not vulnerable to enzyme digestion although cellular contents are readily available to enzymes following cell lysis (Falquet 1997).

Green microalgae with characteristics of multiple ECM groups include Nannochloropsis sp. and Haematococcus sp. Nannochloropsis sp. have a bilayered cell wall structure composed of a cellulosic inner wall and outer layer of hydrophobic algaenan (Scholz et al. 2014). Scholz et al. (2014) proposed that the algaenan structure containing long-chain aliphatic hydrocarbons subject to ether cross-linking reactions (Gelin et al. 1997) confers the recalcitrance characteristics observed in Nannochloropsis sp. Within different strains, cell wall thickness varies considerably, ranging from 63 to $119 \mathrm{~nm}$ (Beacham et al. 2014). Additionally, Nannochloropsis cell walls are rich in various polysaccharides. $N$. oculata polysaccharides are $68 \%$ glucose with $4-8 \%$ of rhamnose, mannose, ribose, xylose, fucose, and galactose (Brown 1991). Similarly, cell wall polysaccharides in $N$. oceania are composed of $90 \%$ glucose, $~ 3 \%$ mannose, traces of rhamnose, fucose, arabinose, xylose, and galactose (Scholz et al. 2014). Haematococcus pluvialis possess thick trilaminar cell walls containing cellulose and sporopollenin, which incurs limited permeability and resistance to mechanical treatments (Safi et al. 2014b). In addition to the trilaminar sheath organization, secondary and tertiary cell walls separate the intracellular environment from the outer cell wall. The trilaminar sheath contains algaenan, with cellulose and mannose composing the secondary and tertiary layers (Kim et al. 2016). The above cell wall structure described for Haematococcus cells is for the mature red cyst with high astaxanthin content as this is the most common morphology encountered during the processing of H. pluvialis.

\section{Traditional ECM disruption techniques}

As noted, the ECM or outermost layer must be disrupted to extract and recover biomolecules. Current cell disruption processes involve the use of energy-intensive equipment, high temperature $\left(>50{ }^{\circ} \mathrm{C}\right)$ treatments, organic solvents, or highly acidic or basic buffers that can potentially decrease product extractability (Wilken and Nikolov 2016). Cell disruption methods can be largely classified into two groups: mechanical and 
non-mechanical. Mechanical methods include bead beating, high pressure or high shear homogenization, ultrasonication, and pulsed electric field. Generally speaking, mechanical methods are less specific to the type of microalgae but are more energy-intensive than non-mechanical methods (Lee et al. 2012). The nonmechanical disruption techniques can be further divided into thermal, chemical, or biological methods (Fig. 2). Chemical disruption while not energy-intensive involves the use of toxic solvents and is not suitable for industrialscale processing (Show et al. 2015). Likewise, biological disruption is a generally regarded as safe (GRAS) process but is not presently cost-effective (Vanthoor-Koopmans et al. 2013; Günerken et al. 2015).

\section{Mechanical methods}

Bead beating Bead beating is the transfer of energy from small beads made of glass, ceramics, or steel to the microalgae cell with mechanical agitation. The cell disruption occurs via compaction or solid shearing when a collision zone between beads is created. Advantages of bead beating include high disruption efficiency, high throughput, reproducibility, and temperature control (Günerken et al. 2015; Al hattab and Ghaly 2015). While this mechanical disruption is regarded for its high efficiency, high energy consumption and costs reduce the applicability of bead beating for microalgae cell disruption. Additional disadvantages include the creation of small cell debris and dispersion of lysate in both the soluble and solid phases, increasing downstream processing costs. Bead beating is most suitable for highly concentrated solutions with products that are easily separated or fractionated after disruption (Show et al. 2015). This technique is applicable for disruption of multiple green microalgae species but particularly advantageous for thick-walled or recalcitrant species such as Nannochloropsis and Chlorella. Processors should note that while application of bead beating will disrupt these species, the resultant lysate will be difficult to fractionate as part of a biorefinery model.

High pressure homogenization High pressure homogenization (HPH) is the pumping or movement of a slurry or cell suspension through a valve at high velocity resulting in shear forces that disrupt cell walls and membranes (Show et al. 2015; Günerken et al. 2015). Advantages include scalability and reproducibility and being chemical/enzyme/toxic substance (solvent) free (GEA Niro Soavi 2011). Disadvantages of HPH include the need for

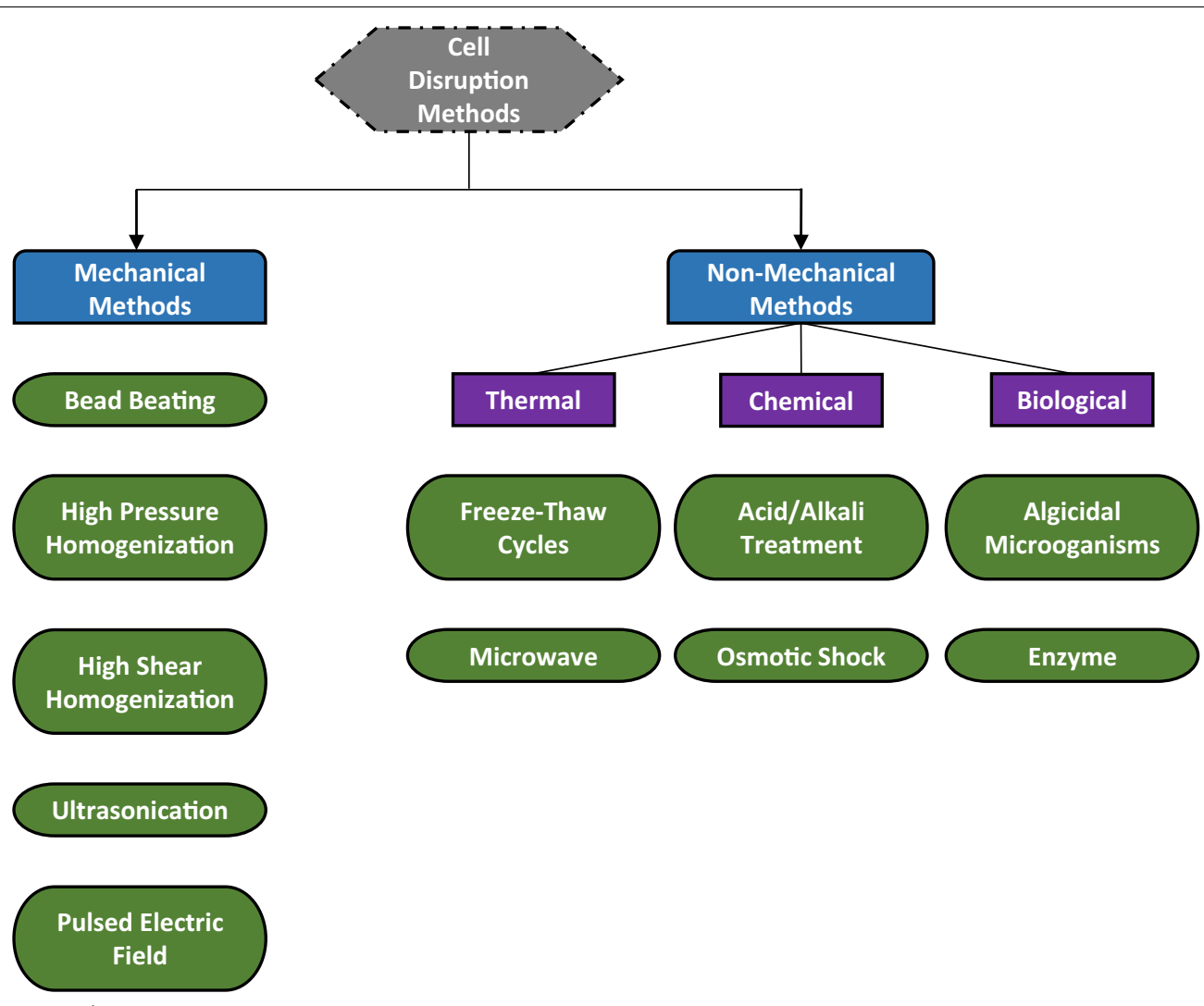

Fig. 2 Cell disruption alternatives 
low dry cell weight concentrations (dilute suspensions) which increase energy demand (Lee et al. 2012) and the creation of small cell debris which increases separation costs (Barba et al. 2015). HPH is commonly used for disruption of Haematococcus cells for fish feed formulations (Chisti and Moo-Young 1986). Additionally, species containing cellulose, algaenan, or sporopollenin such as Chlorella and Nannocholorpsis could be disrupted with HPH. While HPH has proven utility in large-scale operation, high energy demands may limit the technique to recovery of high value products (Yap et al. 2015). HPH could additionally be applicable when cell lysates will be included as part of feed formulation and don't require component fractionation. The technique is also suitable for cells with ECM that are thick-walled, exhibit limited permeability, and are resistant to lower energy mechanical treatments.

High shear homogenization High shear homogenization (HSH) is the stirring or mixing of cell suspension at high speed. Hydrodynamic cavitation and shear forces at solidliquid interfaces disrupt cells prior to subsequent processing. The repeated suction of the cell suspension through the apparatus and subsequent exit through holes at the end of the stator tip results in reduced cellular tissue size. The processing time for $\mathrm{HSH}$ is short and high dry cell weight concentrations can be tolerated (Günerken et al. 2015). Disadvantages include the aggressive nature of the cell disruption and the difficulties of scaling HSH rotorstator apparatus for industrial or commercial scale use. Like HPH, HSH is applicable to multiple green microalgae species but particularly suited for Chlorella and Nannocholorpsis. These species have multilayered ECM rich in polysaccharides and at present are usually used for one target biomolecule. Application of HSH is not ideal for a biorefinery processing model due to the complexity of the resulting cell extracts, which negatively impacts subsequent separation methods, but could be advantageous for cell disruption prior to protein extraction in Chlorella sp. or lipid extraction in Nannochloropsis sp.

Ultrasonication Ultrasonication is the application of high frequency acoustic waves for the disruption of cell walls and membranes. Disruption occurs via two mechanisms: cavitation and acoustic streaming (Gerde et al. 2012). Ultrasound vibrations from the emitting tip can promote cavitation or microbubbles that expand and explode to disrupt surrounding material. In acoustic streaming, the solution is mixed resulting in liquid currents with turbulence that disrupts cellular material. Ultrasonic treatment can disrupt at low temperatures and does not require additional disruption components like beads or chemicals (Al hattab and Ghaly 2015; Wang et al. 2014). Disadvantages include energy consumption, heat production (protein/metabolite denaturation), and inefficiency of disruption of certain algae species. Ultrasonication has been particularly favored for disruption of Spirulina which has an overall weak ECM but can be applied for disruption of Chlorella, Nannochloropsis, Chlamydomonas, and Haematococcus sp. In the later cases, ultrasonic treatment is combined with detergent treatment or solvent systems for increased efficiency and decreased cost demands (Günerken et al. 2015).

Pulsed electric field Pulsed electric field (PEF) treatment is the application of short periods (microseconds) of high voltage electric pulses into cell suspensions situated between two electrodes (Zbinden et al. 2013). Lysed or permeated cell walls and membranes occur through electroporation-associated permeation or pore formation in response to high transmembrane voltage. Pore formation occurs and can be reversible or irreversible depending on PEF intensity (Joannes et al. 2015). The degree of pore formation is dependent on electric field strength, shape/type of pulse, treatment time, and number or pulses (Zbinden et al. 2013; Goettel et al. 2013). Above a certain PEF intensity, reversible pore formation become irreversible wall/ membrane disruption (Zderic et al. 2013). PEF is considered a minimally invasive or gentle disruption technique with advantages including scalability and combination with other disruption treatments. Disadvantages of PEF treatment include the need to deionize solutions for treatment and a decrease in efficiency upon release of internal cellular compounds (Günerken et al. 2015). PEF has broad applicability within green microalgae species such as Nannochloropsis, Haematococcus, Chlorella, and Chlamydomonas as its efficiency can be optimized in terms of energy and electric field strength to permeabilize and/ or partially disrupt various ECM composition. As such, PEF is a technique that can be integrated into a biorefinery process, and when combined with other techniques resulting in complete ECM lysis allow for selective bioproduct extraction at later stages.

\section{Non-mechanical methods}

Microwave treatment Microwave treatment is the uniform, non-contact heating of cellular suspensions that results in moisture evaporation and high pressure bubbles that disrupt cells (Barba et al. 2015; Iqbal and Theegala 2013). Heat in the cell suspension results from rotation and vibration of dipolar molecules and ions in an electromagnetic field (Biller et al. 2013). Advantages include short residence/processing time, scalability, high efficiency, low energy consumption, and low risk of metabolite denaturation (Günerken et al. 2015; Biller et al. 2013; Pasquet et al. 2011). Disadvantages include maintenance costs for industrial-scale treatment and need for cooling 
to maintain product integrity before continued processing ( $\mathrm{Al}$ hattab and Ghaly 2015). Microwave treatment is often combined with other disruption techniques to promote not only disruption but microwave-assisted extraction (MAE) of valuable products. In particular, microwave treatment is commonly applied to Nannochloropsis and Chlorella sp. for extraction of lipids but is broadly applicable to many species for ECM disruption. The resultant lysate would likely be difficult to fractionate as part of a biorefinery process and thus microwave treatment is primarily used when biomass is intended for extraction of one molecule.

Freezing/unfreezing Freezing treatment or freeze-thaw cycles allow for the repeated formation of large intracellular ice crystals that promote pore formation in cell walls and membranes that rupture cells, releasing intracellular compounds (Lee et al. 2012). Freezing can occur slowly in a -15 to $-80{ }^{\circ} \mathrm{C}$ environment or rapidly using liquid nitrogen. Thawing is usually a slow process occurring at room temperature (Henriques et al. 2007). Freezing and thawing for the purpose of cell disruption are associated with high energy consumption and operational/maintenance costs. Additionally, the process is not easily scaled due to treatment or residence times required and the size of freezers necessary for industrial-scale processes. Conversely, this disruption technique does not generate heat and is often utilized at smaller scale for heat-sensitive materials. Freeze-thaw procedures are likely applicable to green microalgae species without a cell wall (Dunaliella) or a fibrillary (cellulose) cell wall (Chlamydomonas, Chlorella, and Spirulina). In these instances, a number of freeze-thaw cycles could be employed to disrupt the cell membrane or one or more layers of a stratified cell wall structure while still allowing for selective extraction of biomolecules at a later processing step.

Chemical application The application of solvents to microalgae is commonly used for lipid or carotenoid extraction, but can be used in coupled cell disruptionextraction procedures. The application of solvents like ethanol, methanol, chloroform, or hexane can have an enhancing effect on cell disruption when cells have been treated with another mechanical or chemical disruption technique. While sparse literature exists on solvent treatment alone, the effectiveness of solvents on disrupted cells is well documented and commonly used method for industrial-scale operations.

Additional chemicals used for cell disruption include acidic solutions (hydrochloric and sulfuric acid), alkaline substances (lime or sodium hydroxide) (Harun and Danquah 2011), lysine, acetone, methanol, or DMSO (Steriti et al. 2014) which are typically added to cells at high temperatures $\left(120-160{ }^{\circ} \mathrm{C}\right)$. Advantages of chemical treatment of cells for disruption include low energy input and scalability (Kim et al. 2013). However, chemical application is not considered to be mild and can have detrimental effects including pigment degradation and protein denaturation. Additional disadvantages include the need for a continuous supply of chemical/solvent, corrosion of equipment by acids or alkalis, and chemical disposal (Kim et al. 2013). As chemical application could include many diverse types of chemicals or solvents, it is applicable to many green microalgae species.

Osmotic shock Osmotic shock is a disruption technique based on the rapid increase or decrease of salt concentration in solution (Amin 2009; Parmar et al. 2011). The stress produced can be hyperosmotic in which cells shrink due to fluid diffusion to the exterior of the cell or hypoosmotic in which cells swell and burst in response to fluid diffusion into the cell. Salts commonly used for osmotic shock disruption include sorbitol and sodium chloride (Bickerton et al. 2016; Drira et al. 2017). Osmotic shock has been previously coupled to other disruption techniques for lipid extraction and $\mathrm{Ca}^{2+}$ signaling response studies in Chlamydomonas reinhardtii, but otherwise has limited utility (Yoo et al. 2012; Bickerton et al. 2016). Use of osmotic shock for green microalgae cell disruption isn't ECM dependent but freshwater species should be exposed to hypertonic conditions and marine species to hypotonic conditions (Yoo et al. 2012). For bioproduct extraction, hypotonic conditions are ideal but disadvantages include inefficiency and the high salinity of resulting wastewater.

Algicidal microorganisms Algicidal microorganisms, previously used for mitigating algal blooms (Bai et al. 2012), can be applied to microalgae cultures for cell wall/ membrane disruption and degradation thought to occur via enzymatic reaction (Chen et al. 2013a, b; Munoz et al. 2014; Lü et al. 2013). Microorganisms (bacteria, cyanobacteria, microalgae themselves, and viruses), co-cultured with microalgae, secrete lytic enzymes to disrupt the cell wall. Interestingly, the co-cultured organisms can be isolated from known microalgae predators and previous work has demonstrated a degree of selectivity and specificity that can be achieved using predator-derived organisms. Chlorella, Nannochloropsis, and Dunaliella species have been successfully disrupted using this technique (Chen et al. 2013a, b; Wang and Yuan 2014; Lenneman et al. 2014). Advantages of algicidal lysis include cost, elimination of need for external enzyme application during downstream processing, high selectivity, and mild extraction conditions ( $\mathrm{pH}$, temperature, etc.) (Demuez et al. 2015). Disadvantages include the need for careful selection of microorganisms, difficulties in establishing 
optimized co-culturing techniques, and controlling the degree of disruption.

\section{Enzymatic hydrolysis for ECM disruption}

The above described mechanical and non-mechanical cell disruption techniques are typically employed as part of a process that focuses on the recovery of one target biomolecule while wasting or inadvertently damaging other potentially valuable biomass components. This highlights the need for selective and targeted disruption of the microalgae cell for recovery of multiple biomolecules. One solution that allows for a biorefinery approach to microalgae biomass processing is enzymatic hydrolysis. Enzymatic hydrolysis of microalgae cell walls and membranes is a mild disruption alternative that allows for processing conditions (mild temperatures, neutral $\mathrm{pH}$, no contact with organic solvent) that maintain the quality and yield of multiple biomolecules. The targeted nature of an enzyme to a specific substrate plays a prominent role in selective disruption and extraction in addition to protecting target biomolecule integrity throughout the disruption process. Potential limitations include the cost of commercial enzymes, lack of knowledge about optimal or compatible enzyme formulations for cell disruption, and the requirement for holding tanks to accommodate long incubation periods (Günerken et al. 2015). Enzyme immobilization or removal following disruption is also necessary for some high value product formulations. As highlighted in "The diversity of extracellular matrices" section, microalgae have vastly diverse ECM but are generally composed of proteins, carbohydrates, and lipids. Thus, enzymes targeting each of these components have potential for disrupting the microalgae cell.

\section{Proteases}

Proteases, an enzyme group that breaks down or cleaves proteins, specifically target amino acid sequence motifs. There are seven families of proteases including serine, cysteine, threonine, aspartic, glutamic, metallo-, and asparagine. Proteases can act near the end of polypeptide chain (exopeptidase) or within the chain (endopeptidase). Protease activity is largely dependent on $\mathrm{pH}$ and temperature and varies widely from one enzyme to another. Common proteases with potential for microalgae cell wall/membrane disruption include trypsin, lysozyme, collagenases, papain, and autolysins (Gerken et al. 2013; Mahdy et al. 2014a; Horst et al. 2012). Preliminary screening of enzymes indicated that proteases may catalyze cell wall disruption for C. vulgaris cells (Mahdy et al. 2014b). Researchers successfully applied Alcalase ${ }^{\circledR}$ (serine endopeptidase) to hydrolyze the C. vulgaris cell wall to enhance biomethane production after anaerobic digestion (Mahdy et al. 2014b). Alcalase ${ }^{\circledR}$ exhibits broad specificity for proteolysis with an optimum $\mathrm{pH}$ of 8.5 and incubation temperature of $\sim 60^{\circ} \mathrm{C}$ and has been commercially utilized for detergent and hydrolysate production (Doucet et al. 2003).

The protease activities of Termamyl ${ }^{\circledR} 120 \mathrm{~L}$ have been used for degradation of glycoproteins in C. reinhardtii cell wall (Choi et al. 2010). Termamyl ${ }^{\circledR} 120$ L contains $\alpha$-amylase and protease activities with an optimum $\mathrm{pH}$ of 7.0 and temperature of $90{ }^{\circ} \mathrm{C}$. The enzyme exhibits great thermostability and has many applications in the food, beverage, and textile industries (Kalegowda et al. 2017; Kłosowski et al. 2015; Raghu and Rajeshwara 2015). Likewise, autolysins have been extensively studied for their ability to hydrolyze the $C$. reinhardtii cell wall (Soto Sierra et al. 2017; Dixon et al. 2016). In particular, gamete autolysin is a cell wall degrading protease induced by nitrogen-deficient stress conditions during sexual reproduction (Jaenicke and Waffenschmidt 1981). Gamete autolysin specifically acts on proline-rich residues within the $C$. reinhardtii cell wall thus allowing for selective extractions. The enzyme has an optimum $\mathrm{pH}$ and incubation temperature for activity of 7.5 and $35{ }^{\circ} \mathrm{C}$, respectively.

\section{Carbohydrases}

Carbohydrases catalyze the breakdown or lysis of carbohydrates into simple sugars. This enzyme group includes glucosidases, galactosidases, amylases, cellulases, chitinases, and pectinases among many others. A common application of carbohydrases in microalgae processing is for saccharification prior to fermentation of simple sugars for biofuel production. As the green microalgae cell wall and/or membrane often contain various polysaccharides, carbohydrase cocktails with multiple enzyme activities are employed to break down the complex polysaccharides. Like proteases, optimum conditions for carbohydrases vary widely depending on type and organism source and selected conditions greatly influence enzyme activity. Horst et al. (2012) determined Viscozyme ${ }^{\circledR} \mathrm{L}$ and Proteinase $\mathrm{K}$ to be candidate enzymes for cell wall disruption of Nannochloropsis oculata cells. Viscozyme ${ }^{\circledR} \mathrm{L}$, an enzyme mixture with arabanase, cellulase, $\beta$-glucanase, hemicellulase, and xylanase activities with optimum activity at $\mathrm{pH} 4.0$ and $50{ }^{\circ} \mathrm{C} . \mathrm{N}$. oculata cell walls have been similarly disrupted and digested with enzyme mixtures of $4 \%$ hemicellulase and $2 \%$ Driselase $^{\circledR}$ (mixture of laminarinase, xylanase, and cellulase activities) (Chen et al. 2008). Driselase ${ }^{\circledR}$ digests plant cell walls with optimum activity at pH 4.5 and $37^{\circ} \mathrm{C}$. Glucanex ${ }^{\circledR}$, Lyticase ${ }^{\circledR}$, and Driselase ${ }^{\circledR}$ have been used as part of an enzyme-assisted cell disruption of $H$. pluvialis cells. Glucane ${ }^{\circledR}$ contains $\beta$-glucanase, cellulase, protease, and chitinase activities. Glucanex ${ }^{\circledR}$ requires mild conditions 
for optimum activity including $\mathrm{pH} 6.0$ and $25{ }^{\circ} \mathrm{C}$ and Lyticase ${ }^{\circledR}$ exhibits optimum activity at $\mathrm{pH} 7.5$ and $25^{\circ} \mathrm{C}$.

\section{Lipases/phospholipases}

Lipases catalyze the hydrolysis of lipids and substrates including specific positions of the glycerol backbone of lipids. A subset of lipases, phospholipases, hydrolyze phospholipids in fatty acids and include four major classes that catalyze specific reactions at different ester bonds. Phospholipase A1 and A2 cleave the $\mathrm{SN}-1$ and SN-2 acyl chains of a phospholipid, respectively. Phospholipase B cleaves both acyl chains and phospholipase $\mathrm{C}$ and phospholipase $\mathrm{D}$ cleave before and after the phosphate, respectively. Like most cell membranes, the main lipid component of microalgae membranes are phospholipids. Thus, phospholipases have potential applicability in disrupting microalgae cell membranes. Phospholipase conditions for optimum activity are between $\mathrm{pH}$ 7.0-9.0 and $25-37^{\circ} \mathrm{C}$. Phospholipase A1 has demonstrated utility in the digestion of Chlorella cell walls, but authors were unable to determine if the actual substrate was phospholipids or the structurally similar algaenan (Gerken et al. 2013). It is important to note that if lipids are the target product, application of lipases/phospholipases for ECM disruption could reduce the total lipid yield as lipid substrates in the cell wouldn't be distinguishable to general use lipase/phospholipase cocktails.

\section{Current applications of aqueous enzymatic processing}

To date, enzymatic hydrolysis of microalgae cells has been used as a pretreatment for extraction and/or conversion of a single target biomolecule. Table 1 presents studies that use enzymes for cell wall pretreatment for the recovery of biomolecules or as part of a bioproduct conversion process. The enzymatic hydrolysis pretreatment is typically followed by a secondary and/or enhancing treatment or processing technique to fully recover or convert the target molecule. Common target products include cell wall carbohydrates, native proteins, lipids, and carotenoids. To gain access to these intracellular products, cells have been treated with enzyme cocktails that encompass many enzymatic activities which target various components in microalgae ECM. After disruption of the cell, secondary application of organic solvents is commonly used for lipid and carotenoid extraction. Carbohydrates recovered after ECM lysis are often fermented or aerobically digested for biofuel production.

\section{Product-containing organelles and disruption strategies}

After lysing the ECM, product-containing organelles must also be disrupted to gain access to target biomolecules. In green microalgae, the chloroplast and lipid droplets are common storage sites of biomolecules and the morphology of each along with cell disruption methods are discussed in the following sections.

\section{Chloroplast structure and disruption strategies}

The chloroplasts of green microalgae are the site of photosynthesis and carbon fixation (Engel et al. 2015) and thus, the chloroplast has a great capacity for accumulation of endogenous proteins, starch, lipids, and pigment/ carotenoids (Franklin and Mayfield 2005). Additionally, green microalgae have well-developed genetic engineering toolkits and can be engineered to produce high value "foreign" or recombinant proteins along with high volume products (lipids) within the chloroplast.

Understanding morphology and internal structure allows for appropriate selection of disruption techniques for recovery of products from the chloroplast. Microalgae chloroplasts can occupy a large percentage of total cell volume (up to 60\%) and are usually cup or basal shaped (Munoz et al. 2014). The chloroplast is generally surrounded by a double envelope membrane and composed internally of thylakoids in bands stacked in irregular patterns. Thylakoids are rich in protein but have membranes dominated by lipids (Simionato et al. 2013). Other components of microalgae chloroplast include photosynthetic pigments, chlorophyll $a$ and chlorophyll $b$, and carotenoids $\alpha$ - and $\beta$-carotene and xanthophylls such as astaxanthin, lutein, zeaxanthin, and neoxanthin (Gong and Bassi 2016; D'Alessandro and Filho 2016).

Previous research into disruption of green microalgae chloroplasts has been for purposes including studying chloroplast proteins, exploring chloroplast DNA and protein synthesis processes, and for identifying proteins induced under specific culturing conditions (Balczun et al. 2006; Bayer et al. 2015; Flores-Pérez and Jarvis 2017). In these instances, researchers isolated intact chloroplasts and then disrupted the organelles using techniques such as freeze-thaw rupture, enzymatic hydrolysis with trypsin and chymotrypsin, and osmotic shock with hypotonic lysis buffers (Bayer et al. 2015; Flores-Pérez and Jarvis 2017). When the chloroplast is disrupted for the purpose of microalgae biorefining, the proteinaceous nature of the outermost membrane can be targeted using a biological-based disruption technique like enzymatic hydrolysis. While use of enzymes for biorefining microalgae is in the development phase, the selective nature of enzymatic hydrolysis has obvious advantages to current chloroplast lysis techniques such as freeze-thaw rupture and osmotic shock. These methods would likely result in a complex lysate requiring additional fractionation steps.

While the protein composition in the membrane can be diverse, general use proteases or cocktail mixtures can potentially cleave and digest peptide bonds. 


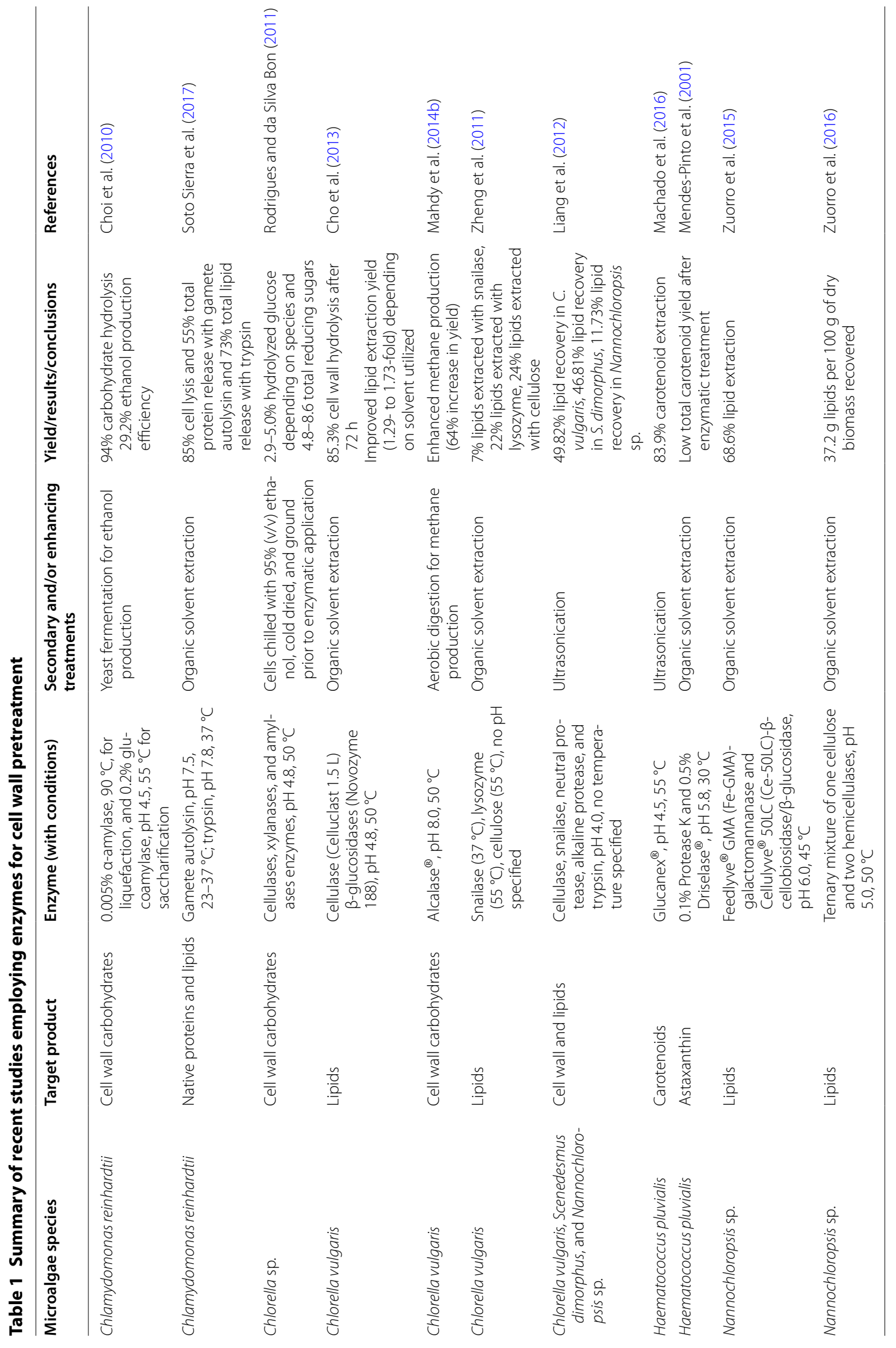


Trypsin, a general serine protease, can cleave various protein substrates. The relatively mild conditions to achieve optimum activity make trypsin a viable candidate for targeting microalgae organelles, particularly the chloroplast. Metalloproteases, which have reported lytic activity against cell walls (Wu and Chen 2011), also have potential in enzymatic hydrolysis of organelle membranes. Bacterial proteases with endopeptidase activities in the neutral $\mathrm{pH}$ range can cleave proteins from a variety of sources which could likely include the membranes of microalgae chloroplasts.

\section{Lipid droplet structure and disruption strategies}

Within the microalgae cell, lipid droplets (LD) are the major site of neutral lipid storage (Goold et al. 2014) and additionally contain valuable products such as carotenoids and pigments. Under nitrogen-replete conditions, green microalgae contain one or two lipid droplets but LD synthesis and accumulation are activated in the presence of stress conditions including nutrient depletion (-N, -Fe, -S, -P), high light, hypoxia, increased salinity, or chemical application (Wang et al. 2009). When stress conditions persist, a metabolic shift or reorganization occurs which leads to the formation of carbon reserves (starch and oil) and a downregulation of photosynthesis and protein synthesis.

The LD comprised a core of triacylglycerols surrounded by a monolayer of polar lipids and proteins interspersed throughout (Goold et al. 2014). For many microalgae species, the major proteins in the LD membrane are generally hydrophobic, maintain the size/structure of LD, and prevent fusion of multiple LD (Moellering and Benning 2009). In C. reinhardtii and D. salina, the most abundant LD membrane protein has been termed major lipid droplet protein (MLDP) (James et al. 2011; Davidi et al. 2012) while those in H. pluvialis and Nannochloropsis sp. have been termed Haematococcus oil globule protein (HOGP) and lipid droplet surface protein (LDSP), respectively (Peled et al. 2011; Vieler et al. 2012). Chlorella sp. contain a homolog of caleosin, an oil-body surface protein found in higher plants, as the most abundant protein in their LD (Lin et al. 2012).

Expellers, presses, or lipophilic solvents are used to disrupt LD and access encased lipids or carotenoids but require prior drying of microalgal biomass (Mubarak et al. 2015). These methods are additionally disadvantageous because of slow processing times and the requirement of large biomass quantities (Harun et al. 2010). Lipophilic solvents can be polar or non-polar and include $n$-hexane, ethanol, 1-butanol, dimethyl ether, and mixtures of chloroform/methanol, $n$-hexane/ethanol, $n$-hexane/isopropanol among others (Neto et al. 2013). At an industrial scale, $n$-hexane is the most used solvent for lipid extraction while chloroform/methanol $(1: 2 \mathrm{v} / \mathrm{v})$ is common for laboratory scale extractions. Mixing polar and non-polar solvents has been demonstrated to promote solvation and lipid recovery (Yoo et al. 2012; Ghasemi Naghdi et al. 2014). Although organic solvents have a long and established history in lipid extraction, the handling and toxicity of the volumes required for commercial scale operations have encouraged development of alternatives for disrupting LD membranes and accessing internal products.

As an alternative to conventional techniques of LD disruption, enzymatic hydrolysis could be employed to target the monolayer of polar lipids or the most abundant membrane protein (MLDP, HOGP, LDSP, caleosin) in LDs. Lipases/phospholipases that can be applied to the ECM for disruption exhibit similar potential for lipid droplet disruption. Additional characterization of lipids in the polar monolayer would allow for selection of a candidate phospholipases/lipases for cleavage and digestion of the lipid droplet membrane. For example, when targeting esters or triglycerides, enzyme preparations with these known substrate specificities could aid in the cleavage of membrane lipids in the lipid droplet.

\section{Future directions of aqueous enzymatic processing} When used for recovery of proteins and oil from microalgae, AEP includes biomass conditioning for maximum enzyme activity, primary enzyme addition, incubation for cell wall disruption and protein solubilization, solvent or detergent-based extraction of biomolecule, and finally centrifugation and biomolecule recovery (Huo et al. 2015; Chen et al. 2016; Wu et al. 2017). An alternative and holistic approach to aqueous enzymatic processing was developed including biomass (biomolecule) production, harvesting, enzymatic degradation of cell wall, enzymatic degradation of organelle membranes, and product separation and fractionation (Soto Sierra et al. 2017). With this process, enzymes were used for cell disruption and for catalyzing product release from internal cellular compartments. There also exists an opportunity for enzymes to disrupt naturally occurring emulsions, facilitating more efficient product separation and fractionation.

After extensive literature review of existing applications of aqueous enzymatic processing, a methodical approach to AEP of various microalgae species was conceived (Fig. 3) by our research group. This systematic approach focuses on the structural composition of the ECM and any product-containing organelles and allows for the processor to select candidate enzymes to facilitate disruption. Considerations before beginning aqueous enzymatic processing include selection of target products, identification of microalgae species for target product accumulation and corresponding ECM, enzyme targets 


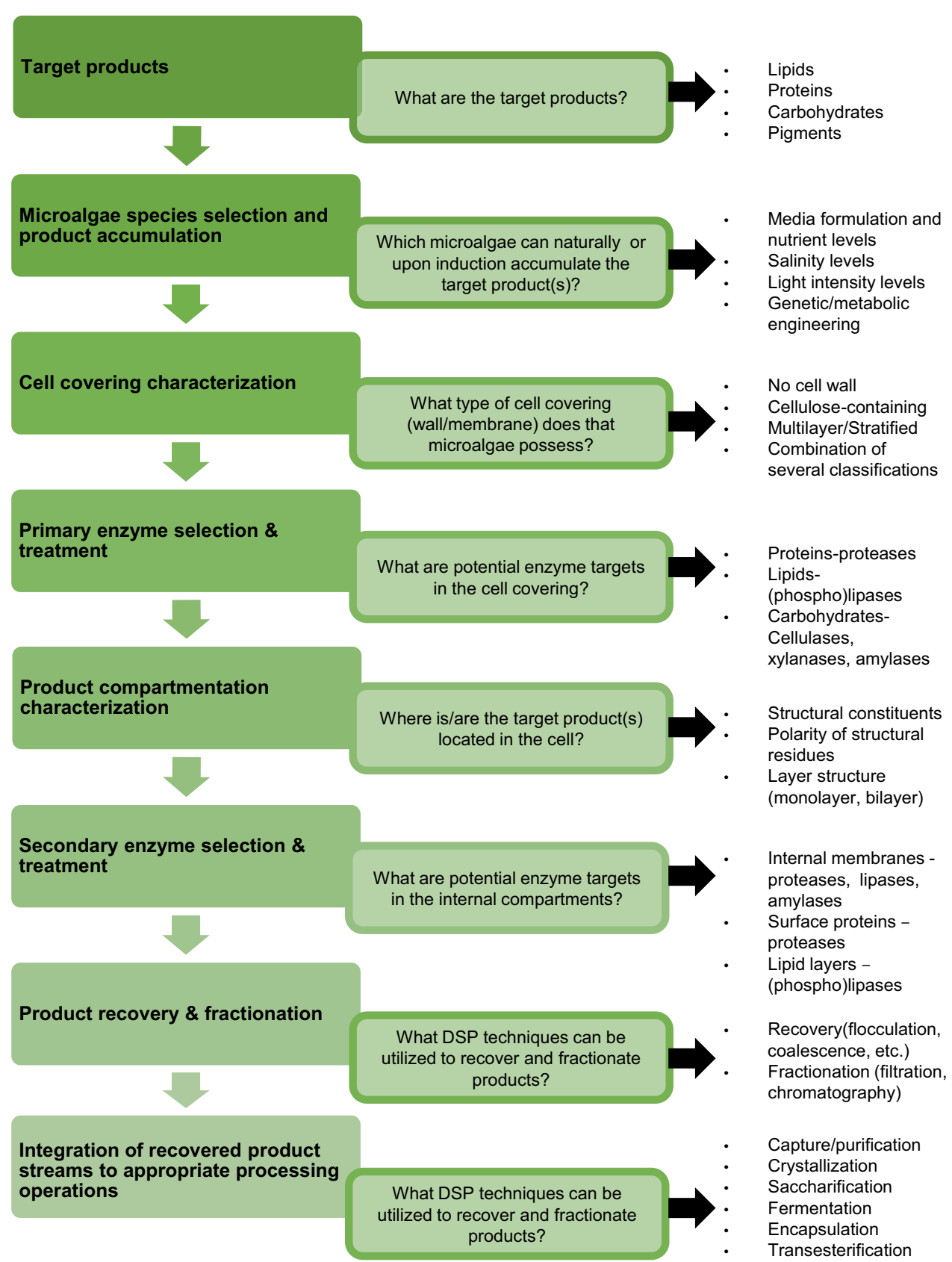

Fig. 3 Aqueous enzymatic processing scheme workflow and design considerations

in the ECM, enzyme targets in product-containing organelles, requirements for additional product processing, and an integration of product streams into final product processing operations.

To assess the applicability of the developed methodology, an evaluation of literature employing enzymatic hydrolysis was conducted with the goal of investigating the methods employed by researchers using microalgae species with similar ECM characteristics. As previously described in "The diversity of extracellular matrices" section, Nannochloropsis and Haematococcus species share cell wall characteristics that include being cellulose containing (fibrillary) and possessing multilayered organization. Enzymes tested for disruption include various commercial enzyme cocktails of cellulases, hemicellulases, amylases, and glucosidase among others. Carbohydrase activity and specificity have demonstrated potential in targeting the polysaccharide-rich 


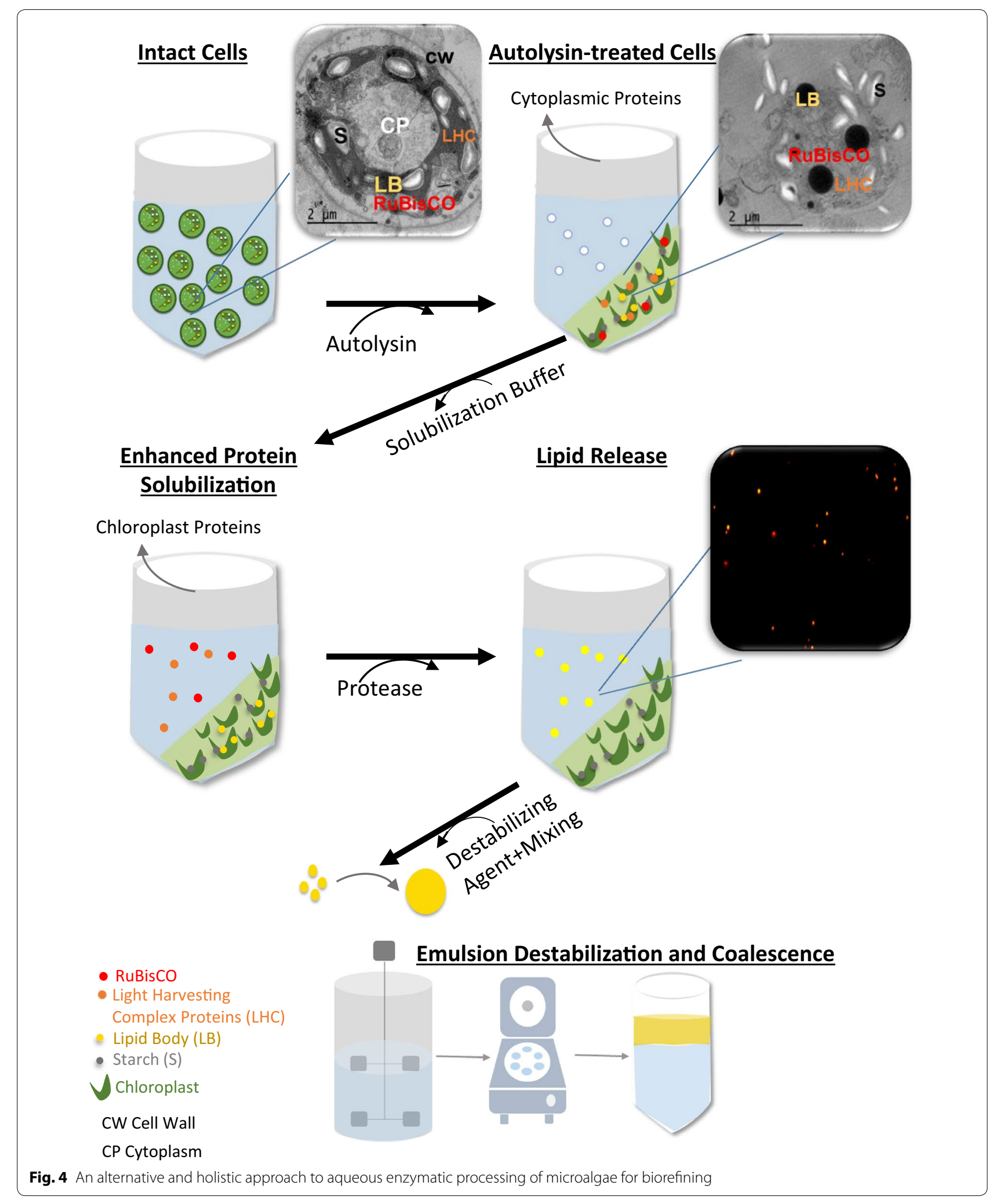


nature of Nannochloropsis and Haematococcus cell walls (Machado et al. 2016; Zuorro et al. 2015). Likewise, Chlamydomonas, Chlorella, and Spirulina species possess multilayered cell walls primarily composed of metabolites including proteins, lipids, and polysaccharides (not including cellulose). Proteases, carbohydrase cocktails, and combined carbohydrase-protease cocktails have been used to target the various metabolites in the cell walls of Chlamydomonas, Chlorella, and Spirulina species (Cho et al. 2013; Choi et al. 2010; Liang et al. 2012; Mahdy et al. 2014b; Soto Sierra et al. 2017). As Dunaliella species possesses a thin plasma membrane instead of a cell wall, enzymes are not used for pretreatment but rather for biomolecule (carotenoid/ pigment) extraction.

Recently, a methodology for native protein and lipid extraction and recovery from wild-type Chlamydomonas reinhardtii was described (Soto Sierra et al. 2017) (Fig. 4). Candidate enzymes selected to potentially target the cellulose-deficient, hydroxyproline-rich cell wall included lysozyme, trypsin, collagenase, and a C. reinhardtii-derived autolysin. Cell wall disruption efficiency was assessed with qualitative and quantitative methods including counting of intact cells after treatment and the application of non-ionic detergents or fluorescent dyes capable of penetrating and staining organelles of cells with disrupted cell walls. Cell wall disruption and native protein release was achieved using gamete autolysin produced by $C$. reinhardtii cells. Analysis revealed that autolysin treatment at $35^{\circ} \mathrm{C}$ for an extended period solubilized more that $50 \%$ of the total protein and resulted in partially disrupted chloroplasts. Following this enzymatic cell wall disruption, remaining proteins and lipid droplet localization in the chloroplast was confirmed. The composition of the chloroplast and lipid droplet membranes was further explored to determine candidate enzymes for cleavage of membrane components and product release. Enzymes include trypsin, Alcalase ${ }^{\circledR}$, DSM metalloprotease (Maxipro ${ }^{\circledR}$ ), and Glucanex ${ }^{\circledR}$. The highest lipid release $(73 \%)$ occurred with the application of trypsin to gamete autolysin-treated cells. In summary, a proof of concept study was conducted to enzymatically hydrolyze the cell wall and organelle membranes of $C$. reinhardtii cells. While native proteins and lipids were extracted and/or released from intracellular compartments, optimized conditions for enzyme application and incubation in addition to fundamentally understanding the enzyme-biomolecule interactions are required. Future efforts should include assessing and modeling the enzymatic hydrolysis approach for multiple biomolecule extraction and recovery for large-scale processing operations.

\section{Conclusions}

Global interests are increasingly pursuing sustainable and renewable sources of energy and other bioproducts. Microalgae has a demonstrated history as a viable biomass source, but established processing techniques have often proved to be cost prohibitive mainly due to energy investments, scalability, and an underutilization of biomass components. The development of extraction and purification methods have traditionally focused on single product recovery and thus may not be suitable or compatible with multiple bioproduct recovery. Researchers have begun using alternative processing techniques such as enzymatic hydrolysis to disrupt microalgae cells and extract and recover multiple biomolecule product precursors with the goal of improving process economics.

To fully realize the effect of alternative processing strategies such as aqueous enzymatic processing, better characterization of microalgae ECMs, organelle membrane compositions, and resultant biomolecule fractions are necessary. Such characterization will allow for producers to assess the effects of enzymatic treatment on the functionality of target biomolecules. This will provide new opportunities for applications of aqueous enzymatic processing for biomolecule recovery or as an enhancing method for traditional recovery schemes. Additionally, connecting morphological characteristics of microalgae ECM and their organelles to implications on process design can serve to improve bioproduct recovery yield and process economics. Thus, researchers and producers can overcome barriers to commercialization by tailoring the processing techniques to both characteristics of the biomass source and target biomolecules.

\section{Abbreviations \\ AEP: aqueous enzymatic processing; $\mathrm{CO}_{2}$ : carbon dioxide; CSFV: classical swine fever virus; DMSO: dimethyl sulfoxide; DSP: downstream processing; ECM: extracellular matrix; EPA: eicosapentaenoic acid; HBsAg: hepatitis B virus surface antigen; HOGP: Haematococcus oil globule protein; HPH: high pressure homogenization; HSH: high shear homogenization; IgG: immunoglobulin G; LD: lipid droplet; LDSP: lipid droplet surface protein; MAE: microwave-assisted extraction; MLDP: major lipid droplet protein; NP-1: neutrophil peptide 1; O\&M: operational and maintenance; PBR: photobioreactor; PEF: pulsed electric} field; RP: recombinant protein; TSP: total soluble protein.

\section{Authors' contributions}

CD and LRW developed manuscript concept, review topics, and structure. CD investigated the references and drafted the manuscript. LRW edited the manuscript. Both authors read and approved the final manuscript.

\section{Acknowledgements}

The authors would like to acknowledge Laura Soto Sierra for her contributions and investigations of the proposed aqueous enzymatic processing of Chlamydomonas reinhardtii.

\section{Competing interests}

The authors declare that they have no competing interests. 


\section{Availability of data and materials}

The authors have no data/materials to deposit. The manuscript is based on a literature review of sources included in the reference list.

\section{Consent for publication}

Not applicable.

Ethics approval and consent to participate

Not applicable.

\section{Funding}

Not applicable.

\section{Publisher's Note}

Springer Nature remains neutral with regard to jurisdictional claims in published maps and institutional affiliations.

Received: 8 January 2018 Accepted: 16 March 2018

Published online: 28 March 2018

\section{References}

Adarme-Vega T, Lim DKY, Timmins M, Vernen F, Li Y, Schenk PM (2012) Microalgal biofactories: a promising approach towards sustainable omega-3 fatty acid production. Microb Cell Fact 11:96. https://doi. org/10.1186/1475-2859-11-96

Ahsan M, Habib B, Parvin M, Huntington TC, Hasan MR (2008) A review on culture, production and use of spirulina as food for humans and feeds for domestic animals. In: FAO fisheries and aquaculture circular. No. 1034. Food and Agriculture Organization of the United Nations. FAO. http:// www.fao.org/3/contents/b2d01d94-4707-54c1-9f65-01f699fc6d07/ i0424e00.htm. Accessed 11 July 2016

Al Hattab M, Ghaly A (2015) Microalgae oil extraction pre-treatment methods: critical review and comparative analysis. J Fundam Renew Energy Appl. https://doi.org/10.4172/2090-4541.1000172

Ali SK, Saleh AM (2012) Spirulina-an overview. Int J Pharm Pharm Sci 4(3):9-15

Amin S (2009) Review on biofuel oil and gas production processes from microalgae. Energy Convers Manag 50:1834-1840. https://doi.org/10.1016/j. enconman.2009.03.001

Apogee Spirulina (2012) Spirulina: the magic food. https://apogeespirulina com/spirulina-magic-food/. Accessed 3 Nov 2016

Bai S, Wang H, Tianling Z (2012) Marine algal viruses and their application in red-tide control. Chin J Appl Environ Biol 18:1056. https://doi. org/10.3724/sp.j.1145.2012.01056

Balczun C, Bunse A, Schwarz C, Piotrowski M, Kück U (2006) Chloroplast heat shock protein cpn60 from Chlamydomonas reinhardtii exhibits a novel function as a group II intron-specific RNA-binding protein. FEBS Lett 580:4527-4532. https://doi.org/10.1016/j.febslet.2006.07.030

Barba FJ, Grimi N, Vorobiev E (2015) New approaches for the use of nonconventional cell disruption technologies to extract potential food additives and nutraceuticals from microalgae. Food Eng Rev 7:45-62. https://doi.org/10.1007/s12393-014-9095-6

Barbosa M, Wijffels R (2015) Outlook on microalgae production chains. http:// library.wur.nl/WebQuery/wurpubs/492293. Accessed 8 Dec 2016

Barros Al, Gonçalves AL, Simões M, Pires JC (2015) Harvesting techniques applied to microalgae: a review. Renew Sustain Energy Rev 41:14891500. https://doi.org/10.1016/j.rser.2014.09.037

Barsanti L, Gualtieri P (2018) Is exploitation of microalgae economically and energetically sustainable? Algal Res 31:107-115. https://doi. org/10.1016/j.algal.2018.02.001

Bayer RG, Stael S, Teige M (2015) Chloroplast isolation and affinity chromatography for enrichment of low-abundant proteins in complex proteomes. In: Posch A (ed) Proteomic profiling. Methods in molecular biology. Humana Press, New York, pp 211-223

BCC Research (2011) Global carotenoids market to reach \$1.4 billion in 2018 . http://www.bccresearch.com/pressroom/fod/global-carotenoidsmarket-reach-\$1.4-billion-2018. Accessed 11 July 2016
Beacham TA, Bradley C, White DA, Bond P, Ali ST (2014) Lipid productivity and cell wall ultrastructure of six strains of Nannochloropsis: implications for biofuel production and downstream processing. Algal Res 6:64-69. https://doi.org/10.1016/j.algal.2014.09.003

Beal CM, Gerber LN, Sills DL et al (2015) Algal biofuel production for fuels and feed in a 100-ha facility: a comprehensive techno-economic analysis and life cycle assessment. Algal Res 11:375-378. https://doi. org/10.1016/j.algal.2015.06.013

Beetul K, Gopeechund A, Kaullysing D, Mattan-Moorgawa S, Puchooa D, Bhagooli R (2016) Challenges and opportunities in the present era of marine algal applications. In: Thajuddin N, Dhanasekaran D (eds) Algae_organisms for imminent biotechnology. InTech, Croatia, pp $237-276$

Belay A (2013) Biology and industrial production of Arthrospira (Spirulina). In: Richmond A, Hu Q (eds) Handbook of microalgal culture: applied phycology and biotechnology. Wiley, Oxford

Benemann J (2013) Microalgae for biofuels and animal feeds. Energies 6:5869-5886. https://doi.org/10.3390/en6115869

Besson A, Guiraud P (2013) High pH induced flocculation flotation of the hypersaline microalga Dunaliella salina. Bioresour Technol 147:464-470. https://doi.org/10.1016/j.biortech.2013.08.053

Bickerton P, Sello S, Brownlee C et al (2016) Spatial and temporal specificity of $\mathrm{Ca}^{2+}$ signalling in Chlamydomonas reinhardtii in response to osmotic stress. New Phytol 212:920-933. https://doi.org/10.1111/nph.14128

Biller P, Friedman C, Ross AB (2013) Hydrothermal microwave processing of microalgae as a pre-treatment and extraction technique for biofuels and bio-products. Bioresour Technol 136:188-195. https://doi. org/10.1016/j.biortech.2013.02.088

Borowitzka MA (1990) The mass culture of Dunaliella salina, In: Regional workshop on the culture and utilization of seaweeds, Cebu City, Philippines, 27-31 Aug 1990

Borowitzka MA (2013) High-value products from microalgae-their development and commercialisation. J Appl Phycol 25:743-756. https://doi. org/10.1007/s10811-013-9983-9

Borowitzka LJ, Borowitzka MA (1990) Commercial production of $\beta$-carotene by Dunaliella salina in open ponds. Bull Mar Sci 47:244-252

Brooks G, Franklin S (2009) Cosmetic compositions comprising microalgal components. US Patent 13,128,217, 9 Nov 2009

Brown MR (1991) The amino-acid and sugar composition of 16 species of microalgae used in mariculture. J Exp Mar Biol Ecol 145:79-99. https:// doi.org/10.1016/0022-0981(91)90007-j

Burlew JS (ed) (1953) Algal culture: from lab to pilot plant, 1st edn. Carnegie Inst of Washington, Washington, D.C.

Camacho-Rodríguez J, Cerón-García M, González-López C, Fernández-Sevilla JM, Contreras-Gómez A, Molina-Grima E (2013) A low-cost culture medium for the production of Nannochloropsis gaditana biomass optimized for aquaculture. Bioresour Technol 144:57-66. https://doi. org/10.1016/j.biortech.2013.06.083

Chauton MS, Reitan KI, Norsker NH, Tveterås R, Kleivdal HT (2015) A technoeconomic analysis of industrial production of marine microalgae as a source of EPA and DHA-rich raw material for aquafeed: research challenges and possibilities. Aquaculture 436:95-103. https://doi. org/10.1016/j.aquaculture.2014.10.038

Chen HL, Li SS, Huang R, Tsai H-J (2008) Conditional production of a functional fish growth hormone in the transgenic line of Nannochloropsis oculata (Eustigmatophyceae). J Phycol 44:768-776. https://doi. org/10.1111/j.1529-8817.2008.00508.x

Chen C-Y, Bai M-D, Chang J-S (2013a) Improving microalgal oil collecting efficiency by pretreating the microalgal cell wall with destructive bacteria. Biochem Eng J 81:170-176. https://doi.org/10.1016/j.bej.2013.10.014

Chen C-Y, Chen Y-C, Huang H-C, Huang C-C, Lee W-L, Chang J-S (2013b) Engineering strategies for enhancing the production of eicosapentaenoic acid (EPA) from an isolated microalga Nannochloropsis oceanica CY2. Bioresour Technol 147:160-167. https://doi.org/10.1016/j. biortech.2013.08.051

Chen C-L, Chang J-S, Lee D-J (2015) Dewatering and drying methods for microalgae. Dry Technol 33:443-454. https://doi.org/10.1080/0737393 7.2014 .997881

Chen L, Li R, Ren X, Liu T (2016) Improved aqueous extraction of microalgal lipid by combined enzymatic and thermal lysis from wet biomass of 
Nannochloropsis oceanica. Bioresour Technol 214:138-143. https://doi. org/10.1016/j.biortech.2016.04.031

Chia SR, Chew KW, Show PL et al (2018). Analysis of economic and environmental aspects of microalgae biorefinery for biofuels production: a review. Biotechnol J 1700618. https://doi.org/10.1002/biot.201700618

Chisti Y, Moo-Young M (1986) Disruption of microbial cells for intracellular products. Enzyme Microb Technol 8:194-204. https://doi. org/10.1016/0141-0229(86)90087-6

Cho H-S, Oh Y-K, Park S-C, Lee J-W, Park J-Y (2013) Effects of enzymatic hydrolysis on lipid extraction from Chlorella vulgaris. Asia Pac Forum Renew Energy 54:156-160. https://doi.org/10.1016/j.renene.2012.08.031

Choi SP, Nguyen MT, Sim SJ (2010) Enzymatic pretreatment of Chlamydomonas reinhardtii biomass for ethanol production. Bioresour Technol 101:5330-5336. https://doi.org/10.1016/j.biortech.2010.02.026

Ciferri O (1983) Spirulina, the edible microorganism. Microbiol Rev 47:551-578

Converti A, Casazza AA, Ortiz EY, Perego P, Del Borghi M (2009) Effect of temperature and nitrogen concentration on the growth and lipid content of Nannochloropsis oculata and Chlorella vulgaris for biodiesel production. Chem Eng Process Process Intensif 48:1146-1151. https:// doi.org/10.1016/j.cep.2009.03.006

Coragliotti A, Franklin S, Day AG, Decker SM (2010) Microalgal polysaccharide compositions. US Patent 13,260,546 29 Mar 2010

Cuellar-Bermudez SP, Aguilar-Hernandez I, Cardenas-Chavez DL, Ornelas-Soto N, Romero-Ogawa MA, Parra-Saldivar R (2014) Extraction and purification of high-value metabolites from microalgae: essential lipids, astaxanthin and phycobiliproteins. Microb Biotechnol 8:190-209. https://doi. org/10.1111/1751-7915.12167

D'Alessandro EB, Filho NRA (2016) Concepts and studies on lipid and pigments of microalgae: a review. Renew Sustain Energy Rev 58:832-841. https:// doi.org/10.1016/j.rser.2015.12.162

Davidi L, Katz A, Pick U (2012) Characterization of major lipid droplet proteins from Dunaliella. Planta 236:19-33. https://doi.org/10.1007/ s00425-011-1585-7

Davis R, Aden A, Pienkos PT (2011) Techno-economic analysis of autotrophic microalgae for fuel production. Appl Energy 88:3524-3531. https://doi. org/10.1016/j.apenergy.2011.04.018

Demuez M, González-Fernández C, Ballesteros M (2015) Algicidal microorganisms and secreted algicides: new tools to induce microalgal cell disruption. Biotechnol Adv 33:1615-1625. https://doi.org/10.1016/j. biotechadv.2015.08.003

Demurtas OC, Massa S, Ferrante P et al (2013) A Chlamydomonas-derived human papillomavirus $16 \mathrm{e} 7$ vaccine induces specific tumor protection. PLoS ONE 8:e61473. https://doi.org/10.1371/journal.pone.0061473

Dixon C, Soto Sierra L, Wilken LR (2016) Enzymatic cell wall disruption for the extraction of valuable bioproducts from Chlamydomonas reinhardtii. Paper presented at 2016 ASABE Annual International Meeting, Orlando, Florida, 17-20 July 2016

Domozych DS, Ciancia M, Fangel JU, Mikkelsen M, Ulvskov P, Willats W (2012) The cell walls of green algae: a journey through evolution and diversity. Front Plant Sci. https://doi.org/10.3389/fpls.2012.00082

Doucet D, Otter DE, Gauthier SF, Foegeding EA (2003) Enzyme-induced gelation of extensively hydrolyzed whey proteins by Alcalase: peptide identification and determination of enzyme specificity. J Agric Food Chem 51:6300-6308. https://doi.org/10.1021/jf026242v

Drira N, Dhouibi N, Hammami S et al (2017) Fatty acids from high rate algal pond's microalgal biomass and osmotic stress effects. Bioresour Technol 244:860-864. https://doi.org/10.1016/j.biortech.2017.08.052

Engel BD, Schaffer M, Cuellar LK, Villa E, Plitzko JM, Baumeister W (2015) Native architecture of the Chlamydomonas chloroplast revealed by in situ cryo-electron tomography. eLife 4:e11383. https://doi.org/10.7554/ elife. 11383

Ericksen NT (2016) Research trends in the dominating microalgal pigments, $\beta$-carotene, astaxanthin, and phycocyanin used in feed, in foods, and in health applications. J Nutr Food Sci. https://doi. org/10.4172/2155-9600.1000507

Falquet J, Hurni JP (1997) The nutritional aspects of Spirulina. Antenna Foundation. Available via https://www.antenna.ch/wp-content/ uploads/2017/03/AspectNut_UK.pdf. Accessed 13 July 2016

Flores-Pérez Ú, Jarvis P (2017) Isolation and suborganellar fractionation of Arabidopsis chloroplasts. In: Taylor N, Millar A (eds) Isolation of plant organelles and structures. Methods in molecular biology. Humana Press, New York, pp 45-60

Franklin SE, Mayfield SP (2005) Recent developments in the production of human therapeutic proteins in eukaryotic algae. Expert Opin Biol Ther 5:225-235. https://doi.org/10.1517/14712598.5.2.225

GEA Niro Soavi (2011) Cells disruption by means of high pressure homogenization. http://www.pharmaceuticalonline.com/doc/high-pressurehomogenization-insuline-0002. Accessed 112016

Gelin F, Volkman JK, Leeuw JWD, Damsté JSS (1997) Mid-chain hydroxy longchain fatty acids in microalgae from the genus Nannochloropsis. Phytochemistry 45:641-646. https://doi.org/10.1016/s0031-9422(97)00068-x

Gerardo ML, Hende SVD, Vervaeren $\mathrm{H}$ et al (2015) Harvesting of microalgae within a biorefinery approach: a review of the developments and case studies from pilot-plants. Algal Res 11:248-262. https://doi. org/10.1016/j.algal.2015.06.019

Gerde JA, Montalbo-Lomboy M, Yao L, Grewell D, Wang T (2012) Evaluation of microalgae cell disruption by ultrasonic treatment. Bioresour Technol 125:175-181. https://doi.org/10.1016/j.biortech.2012.08.110

Gerken HG, Donohoe B, Knoshaug EP (2013) Enzymatic cell wall degradation of Chlorella vulgaris and other microalgae for biofuels production. Planta 237:239-253. https://doi.org/10.1007/s00425-012-1765-0

Ghasemi Naghdi F, Thomas-Hall SR, Durairatnam R, Pratt S, Schenk PM (2014) Comparative effects of biomass pre-treatments for direct and indirect transesterification to enhance microalgal lipid recovery. Front Energy Res 2:57. https://doi.org/10.3389/fenrg.2014.00057

Gnansounou E, Raman JK (2016) Life cycle assessment of algae biodiesel and its co-products. Appl Energy 161:300-308. https://doi.org/10.1016/j. apenergy.2015.10.043

Goettel M, Eing C, Gusbeth C, Straessner R, Frey W (2013) Pulsed electric field assisted extraction of intracellular valuables from microalgae. Algal Res 2:401-408. https://doi.org/10.1016/j.algal.2013.07.004

Gong M, Bassi A (2016) Carotenoids from microalgae: a review of recent developments. Biotechnol Adv 34:1396-1412. https://doi.org/10.1016/j. biotechadv.2016.10.005

Goodenough UW (1985) The Chlamydomonas cell wall and its constituent glycoproteins analyzed by the quick-freeze, deep-etch technique. J Cell Biol 101:1550-1568. https://doi.org/10.1083/jcb.101.4.1550

Goold H, Beisson F, Peltier G, Li-Beisson Y (2014) Microalgal lipid droplets: composition, diversity, biogenesis and functions. Plant Cell Rep 34:545-555. https://doi.org/10.1007/s00299-014-1711-7

Günerken E, Dhondt E, Eppink M, Garcia-Gonzalez L, Elst K, Wijffels RH (2015) Cell disruption for microalgae biorefineries. Biotechnol Adv 33:243-260. https://doi.org/10.1016/j.biotechadv.2015.01.008

Guo Y, Yeh T, Song W et al (2015) A review of bio-oil production from hydrothermal liquefaction of algae. Renew Sustain Energy Rev 48:776-790. https://doi.org/10.1016/j.rser.2015.04.049

Gutiérrez-Arriaga CCAG, Serna-González M, Ponce-Ortega JM, El-Halwagi MM (2014) Sustainable integration of algal biodiesel production with steam electric power plants for greenhouse gas mitigation. ACS Sustain Chem Eng 2:1388-1403. https://doi.org/10.1021/sc400436a

Guzmán-Zapata D, Macedo-Osorio KS, Almaraz-Delgado AL, Durán-Figueroa $\mathrm{N}$, Badillo-Corona JA (2016) Production of recombinant proteins in the chloroplast of the green alga Chlamydomonas reinhardtii. In: MacDonald J, Kolotilin I, Menassa R (eds) Recombinant proteins from plants. Methods in molecular biology, vol 1385. Humana Press, New York, NY, 69-85. https://doi.org/10.1007/978-1-4939-3289-4_5

Haghjou MM, Shariati M (2007) Photosynthesis and respiration under low temperature stress in two Dunaliella strains. World Appl Sci J 2:276-282

Harun R, Danquah MK (2011) Influence of acid pre-treatment on microalgal biomass for bioethanol production. Process Biochem 46:304-309. https://doi.org/10.1016/j.procbio.2010.08.027

Harun R, Singh M, Forde GM, Danquah MK (2010) Bioprocess engineering of microalgae to produce a variety of consumer products. Renew Sustain Energy Rev 14:1037-1047. https://doi.org/10.1016/j.rser.2009.11.004

Hempel F, Maier UG (2016) Microalgae as solar-powered protein factories. In: Vega M (ed) Advanced technologies for protein complex production and characterization, vol 896. Springer, Cham, pp 241-262

Henriques M, Silva A, Rocha J (2007) Extraction and quantification of pigments from a marine microalga: a simple and reproducible method. In: Méndez-Vilas A (ed) Communicating current research and educational 
topics and trends in applied microbiology. Formatex, Badajoz, pp 586-593

Hernández D, Riaño B, Coca M, García-González M (2015) Saccharification of carbohydrates in microalgal biomass by physical, chemical and enzymatic pre-treatments as a previous step for bioethanol production. Chem Eng J 262:939-945. https://doi.org/10.1016/j.cej.2014.10.049

Horst I, Parker BM, Dennis JS, Howe CJ, Scott SA, Smith AG (2012) Treatment of Phaeodactylum tricornutum cells with papain facilitates lipid extraction. J Biotechnol 162:40-49. https://doi.org/10.1016/j.jbiotec.2012.06.033

Huang Y, Qin S, Zhang D, Li L, Mu Y (2016) Evaluation of cell disruption of Chlorella vulgaris by pressure-assisted ozonation and ultrasonication. Energies 9:173. https://doi.org/10.3390/en9030173

Hudek K, Davis L, Ibbini J, Erickson L (2014) Commercial products from algae. In: Bajpai R, Prokop A, Zappi M (eds) Algal biorefineries. Springer, Amsterdam, pp 275-295

Huo S, Wang Z, Cui F et al (2015) Enzyme-assisted extraction of oil from wet microalgae Scenedesmus sp. G4. Energies 8:8165-8174. https://doi. org/10.3390/en8088165

Imam SY, Snell WJ (1988) The Chlamydomonas cell wall degrading enzyme, lysin, acts on two substrates within the framework of the wall. Appl Environ Microbiol 53:1701-1704

Industry Experts (2015) Global astaxanthin market—-sources, technologies and applications. http://industry-experts.com/verticals/healthcare-andpharma/global-astaxanthin-market-sources-technologies-and-applications. Accessed 11 July 2016

Iqbal J, Theegala C (2013) Microwave assisted lipid extraction from microalgae using biodiesel as co-solvent. Algal Res 2:34-42. https://doi. org/10.1016/j.algal.2012.10.001

Jaenicke L, Waffenschmidt S (1981) Liberation of reproductive units in Volvox and Chlamydomonas: proteolytic processes. Plant Biol 94:375-386. https://doi.org/10.1111/j.1438-8677.1981.tb03413.x

James GO, Hocart CH, Hillier W, Chen H, Kordbacheh F, Price GD, Djordjevic MA (2011) Fatty acid profiling of Chlamydomonas reinhardtii under nitrogen deprivation. Bioresour Technol 102:3343-3351. https://doi. org/10.1016/j.biortech.2010.11.051

Jegathese SJP, Farid M (2014) Microalgae as a renewable source of energy: a niche opportunity. J Renew Energy 2014:1-10. https://doi. org/10.1155/2014/430203

Joannes C, Sipaut CS, Dayou J, Yasir SM, Mansa RF (2015) The potential of using pulsed electric field (pef) technology as the cell disruption method to extract lipid from microalgae for biodiesel production. IJRER 5(2):598-621

Kalegowda P, Chauhan AS, Nanjarajurs SM (2017) Opuntia dillenii (Ker-gawl) haw fruit peel pectin: physicochemical, rheological, and functional behavior. J Food Process Preserv. https://doi.org/10.1111/jfpp.13165

Kim S-Y, Cho E-A, Yoo J-M, In M-J, Chae H-J (2008) Solubility and storage stability of astaxanthin. KSBB J 23:546-550

Kim J, Yoo G, Lee H, Lim J, Kim K, Kim CW, Park MS, Yang J-W (2013) Methods of downstream processing for the production of biodiesel from microalgae. Biotechnol Adv 31:862-876. https://doi.org/10.1016/j. biotechadv.2013.04.006

Kim D-Y, Vijayan D, Praveenkumar R, Han J-I, Lee K, Park J-Y, Chang W-S, Lee J-S, Oh Y-K (2016) Cell-wall disruption and lipid/astaxanthin extraction from microalgae: Chlorella and Haematococcus. Bioresour Technol 199:300-310. https://doi.org/10.1016/..biortech.2015.08.107

Kleinegris DMM, Janssen M, Brandenburg WA, Wijffels RH (2009) The selectivity of milking of Dunaliella salina. Mar Biotechnol 12:14-23. https://doi. org/10.1007/s10126-009-9195-0

Kłosowski G, Mikulski D, Macko D, Miklaszewska B, Kotarska K, Czupryński $B$ (2015) Influence of various yeast strains and selected starchy raw materials on production of higher alcohols during the alcoholic fermentation process. Euro Food Res Technol 240(1):233-242. https://doi. org/10.1007/s00217-014-2323-8

Kyriakopoulou K, Papadaki S, Krokida M (2015) Life cycle analysis of $\beta$-carotene extraction techniques. J Food Eng 167:51-58. https://doi.org/10.1016/j. jfoodeng.2015.03.008

Lam MK, Lee KT (2012) Microalgae biofuels: a critical review of issues, problems and the way forward. Biotechnol Adv 30:673-690. https://doi. org/10.1016/j.biotechadv.2011.11.008

Lee AK, Lewis DM, Ashman PJ (2012) Disruption of microalgal cells for the extraction of lipids for biofuels: processes and specific energy requirements. Biomass Bioenergy 46:89-101. https://doi.org/10.1016/j. biombioe.2012.06.034

Lenneman EM, Wang P, Barney BM (2014) Potential application of algicidal bacteria for improved lipid recovery with specific algae. FEMS Microbol Lett 354:102-110. https://doi.org/10.1111/1574-6968.12436

Liang K, Zhang Q, Cong W (2012) Enzyme-assisted aqueous extraction of lipid from microalgae. J Agric Food Chem 60:11771-11776. https://doi. org/10.1021/jf302836V

Lin I-P, Jiang P-L, Chen C-S, Tzen JT (2012) A unique caleosin serving as the major integral protein in oil bodies isolated from Chlorella sp. cells cultured with limited nitrogen. Plant Physiol Biochem 61:80-87. https:// doi.org/10.1016/j.plaphy.2012.09.008

Liu J, Chen F (2014) Biology and industrial applications of Chlorella: advances and prospects. In: Posten C, Feng Chen S (eds) Microalgae biotechnology, vol 153. Springer, Cham, pp 1-35

Lü F, Ji J, Shao L, He P (2013) Bacterial bioaugmentation for improving methane and hydrogen production from microalgae. Biotechnol Biofuels 6:92. https://doi.org/10.1186/1754-6834-6-92

Ma X-N, Chen T-P, Yang B, Li J, Chen F (2016) Lipid production from Nannochloropsis. Mar Drugs 14:61. https://doi.org/10.3390/md14040061

Machado FR, Trevisol TC, Boschetto DL, Burkert JFM, Ferreira SRS, Oliveira JV, Burkert CAV (2016) Technological process for cell disruption, extraction and encapsulation of astaxanthin from Haematococcus pluvialis. J Biotechnol 218:108-114. https://doi.org/10.1016/j.jbiotec.2015.12.004

Mahdy A, Mendez L, Ballesteros M, González-Fernández C (2014a) Enhanced methane production of Chlorella vulgaris and Chlamydomonas reinhardtii by hydrolytic enzymes addition. Energy Convers Manag 85:551-557. https://doi.org/10.1016/j.enconman.2014.04.097

Mahdy A, Mendez L, Blanco S, Ballesteros M, González-Fernández C (2014b) Protease cell wall degradation of Chlorella vulgaris: effect on methane production. Bioresour Technol 171:421-427. https://doi.org/10.1016/j. biortech.2014.08.091

Markou G, Nerantzis E (2013) Microalgae for high-value compounds and biofuels production: a review with focus on cultivation under stress conditions. Biotechnol Adv 31:1532-1542. https://doi.org/10.1016/j. biotechadv.2013.07.011

Mendes-Pinto MM, Raposo MFJ, Bowen J, Young AJ, Morais R (2001) Evaluation of different cell disruption processes on encysted cells of Haematococcus pluvialis: effects on astaxanthin recovery and implications for bio-availability. J Appl Phycol 13:19-24. https://doi.org/10.102 3/A:1008183429747

Mercer P, Armenta RE (2011) Developments in oil extraction from microalgae. Eur J Lipid Sci Technol 113:539-547

Milledge JJ (2010) Commercial application of microalgae other than as biofuels: a brief review. Rev Environ Sci Bio/Technol 10:31-41. https://doi. org/10.1007/s11157-010-9214-7

Milne JJ (2017) Scale-up of protein purification: downstream processing issues. In: Walls D, Loughran S (eds) Protein chromatography. Methods in molecular biology. Humana Press, New York, pp 71-84

Moellering ER, Benning C (2009) RNA interference silencing of a major lipid droplet protein affects lipid droplet size in Chlamydomonas reinhardtii. Eukaryot Cell 9:97-106. https://doi.org/10.1128/ec.00203-09

Monte J, Sá M, Galinha CF, Costa L, Hoekstra H, Brazinha C, Crespo JG (2018) Harvesting of Dunaliella salina by membrane filtration at pilot scale. Sep Purif Technol 190:252-260. https://doi.org/10.1016/j.seppur.2017.08.019

Mourelle M, Gómez C, Legido J (2017) The potential use of marine microalgae and cyanobacteria in cosmetics and thalassotherapy. Cosmetics 4:46. https://doi.org/10.3390/cosmetics4040046

Mubarak M, Shaija A, Suchithra T (2015) A review on the extraction of lipid from microalgae for biodiesel production. Algal Res 7:117-123. https:// doi.org/10.1016/j.algal.2014.10.008

Munjal N, Garzon-Sanabria A, Quinones K, Gregory J, Nikolov ZL (2014) Lightinduced production of an antibody fragment and malaria vaccine antigen from Chlamydomonas reinhardtii. Processes 2:625-638. https:// doi.org/10.3390/pr2030625

Munjal N, Kulkarni S, Quinones K, Tran M, Mayfield SP, Nikolov ZL (2015) Evaluation of pretreatment methods for primary recovery and capture of an antibody fragment (aCD22scFv) from Chlamydomonas reinhardtii lysates. Algal Res 12:455-462. https://doi.org/10.1016/j. algal.2015.10.011 
Munoz C, Hidalgo C, Zapata M, Jeison D, Riquelme C, Rivas M (2014) Use of cellulolytic marine bacteria for enzymatic pretreatment in microalgal biogas production. Appl Environ Microbiol 80:4199-4206. https://doi. org/10.1128/aem.00827-14

Narala RR, Garg S, Sharma KK et al (2016) Comparison of microalgae cultivation in photobioreactor, open raceway pond, and a two-stage hybrid system. Front Energy Res. https://doi.org/10.3389/fenrg.2016.00029

Neto AMP, Souza RASD, Leon-Nino AD, da Costa JDA, Tiburcio RS, Nunes TA, de Mello TCS, Kanemoto FT, Saldanha-Corrêa FMP, Gianesella SMF (2013) Improvement in microalgae lipid extraction using a sonicationassisted method. Renew Energy 55:525-531. https://doi.org/10.1016/j. renene.2013.01.019

Nguyen A, Tran D, Ho M et al (2016) High light stress regimen on Dunaliella salina strains for carotenoids induction. IFNB 3:347-350. https://doi. org/10.15761/ifnm.1000158

Nobre BP, Villalobos F, Barragán BE, Oliveira AC, Batista AP, Marques P, Mendes RL, Sovová H, Palavra AF, Gouveia L (2013) A biorefinery from Nannochloropsis sp. microalga - extraction of oils and pigments. Production of biohydrogen from the leftover biomass. Bioresour Technol 135:128-136. https://doi.org/10.1016/j.biortech.2012.11.084

Norsker N-H, Barbosa MJ, Vermuë MH, Wijffels RH (2011) Microalgal production-a close look at the economics. Biotechnol Adv 29:24-27. https:// doi.org/10.1016/j.biotechadv.2010.08.005

Oilgae (2016) Emerging algae product and business opportunities. http:// www.oilgae.com/ref/wp/downloads/emerging-algae-products-andbusiness-opportunities.pdf. Accessed 8 Dec 2016

Packaged Facts (2012) The global market for EPA/DHA omega-3 products. http://www.packagedfacts.com/Global-EPA-DHA-7145087/. Accessed 11 July 2016

Panis G, Carreon JR (2016) Commercial astaxanthin production derived by green alga Haematococcus pluvialis: a microalgae process model and a techno-economic assessment all through production line. Algal Res 18:175-190. https://doi.org/10.1016/j.algal.2016.06.007

Parmar A, Singh NK, Pandey A et al (2011) Cyanobacteria and microalgae: a positive prospect for biofuels. Bioresour Technol 102:10163-10172. https://doi.org/10.1016/j.biortech.2011.08.030

Pasquet V, Chérouvrier J-R, Farhat F, Thiéry V, Piot J-M, Bérard J-B, Kaas R, Serive B, Patrice T, Cadoret J-P (2011) Study on the microalgal pigments extraction process: performance of microwave assisted extraction. Process Biochem 46:59-67. https://doi.org/10.1016/j.procbio.2010.07.009

Pearsall R, Connelly R, Fountain M, Hearn CS, Werst MD, Hebner RE, Kelley EF (2011) Electrically dewatering microalgae. IEEE Trans Dielectr Electr Insul 18:1578-1583. https://doi.org/10.1109/tdei.2011.6032827

Peled E, Leu S, Zarka A, Weiss M, Pick U, Khozin-Goldberg I, Boussiba S (2011) Isolation of a novel oil globule protein from the green alga Haematococcus pluvialis (Chlorophyceae). Lipids 46:851-861. https://doi. org/10.1007/s11745-011-3579-4

Polle JEW, Barry K, Cushman J et al (2017) Draft nuclear genome sequence of the halophilic and beta-carotene-accumulating green alga Dunaliella salina strain CCAP19/18. Genome Announc 5:e01105-e01117. https:// doi.org/10.1128/genomea.01105-17

Popper ZA, Michel G, Hervé C, Domozych DS, Willats WGT, Tuohy MG, Kloareg B, Stengel DB (2011) Evolution and diversity of plant cell walls: from algae to flowering plants. Annu Rev Plant Biol 62:567-590. https://doi. org/10.1146/annurev-arplant-042110-103809

Raghu HS, Rajeshwara NA (2015) Immobilization of a-amylase (1,4-a-D glucanglucano hydralase) by calcium alginate encapsulation. IFRJ. 22(2):869-871

Raja R, Hemaiswarya S, Rengasamy R (2007) Exploitation of Dunaliella for $\beta$-carotene production. Appl Microbiol Biotechnol 74:517-523. https:// doi.org/10.1007/s00253-006-0777-8

Rajendran N, Puppala S, Sneha Raj M, Ruth Angeeleena B, Rajam C (2012) Seaweeds can be a new source for bioplastics. J Pharm Res 5:1476-1479

Ramaraj R, Unpaprom Y, Dussadee N (2016) Cultivation of green microalga, Chlorella vulgaris for biogas purification. Int J New Technol Res 2:117-122

Rasala BA, Mayfield SP (2011) The microalga Chlamydomonas reinhardtii as a platform for the production of human protein therapeutics. Bioeng Bugs 2:50-54. https://doi.org/10.4161/bbug.2.1.13423

Rasala BA, Mayfield SP (2015) Photosynthetic biomanufacturing in green algae; production of recombinant proteins for industrial, nutritional, and medical uses. Photosynth Res 123:227-239. https://doi.org/10.1007/ s11120-014-9994-7

Ríos SD, Torres CM, Torras C et al (2013) Microalgae-based biodiesel: economic analysis of downstream process realistic scenarios. Bioresour Technol 136:617-625. https://doi.org/10.1016/j.biortech.2013.03.046

Rodrigues MA, da Silva Bon EP (2011) Evaluation of Chlorella (Chlorophyta) as source of fermentable sugars via cell wall enzymatic hydrolysis. Enzyme Res 2011:1-5. https://doi.org/10.4061/2011/405603

Safi C, Ursu AV, Laroche C, Zebib B, Merah O, Pontalier P-Y, Vaca-Garcia C (2014a) Aqueous extraction of proteins from microalgae: effect of different cell disruption methods. Algal Res 3:61-65. https://doi. org/10.1016/j.algal.2013.12.004

Safi C, Zebib B, Merah O, Pontalier P-Y, Vaca-Garcia C (2014b) Morphology, composition, production, processing and applications of Chlorella vulgaris: a review. Renew Sustain Energy Rev 35:265-278. https://doi. org/10.1016/j.rser.2014.04.007

Sahay S, Braganza VJ (2016) Microalgae based biodiesel production-current and future scenario. J Exp Sci 7:31-35. https://doi.org/10.19071/ jes.2016.v7.3027

Sarada R, Tripathi U, Ravishankar G (2002) Influence of stress on astaxanthin production in Haematococcus pluvialis grown under different culture conditions. Process Biochem 37:623-627. https://doi.org/10.1016/ s0032-9592(01)00246-1

Scaife MA, Nguyen GTDT, Rico J, Lambert D, Helliwell KE, Smith AG (2015) Establishing Chlamydomonas reinhardtii as an industrial biotechnology host. Plant J 82:532-546. https://doi.org/10.1111/tpj.12781

Scholz MJ, Weiss TL, Jinkerson RE, Jing J, Roth R, Goodenough U, Posewitz MC, Gerken HG (2014) Ultrastructure and composition of the Nannochloropsis gaditana cell wall. Eukaryot Cell 13:1450-1464. https://doi. org/10.1128/ec.00183-14

Scranton MA, Ostrand JT, Fields FJ, Mayfield SP (2015) Chlamydomonas as a model for biofuels and bio-products production. Plant J 82:523-531. https://doi.org/10.1111/tpj.12780

Shah MMR, Liang Y, Cheng JJ, Daroch M (2016) Astaxanthin-producing green microalga Haematococcus pluvialis: from single cell to high value commercial products. Front Plant Sci 7:531. https://doi.org/10.3389/ fpls.2016.00531

Shariati M, Hadi MR (2011) Microalgal biotechnology and bioenergy in Dunaliella. In: Carpi A (ed) Progress in molecular and environmental bioengineering — from analysis and modeling to technology applications. InTech, Croatia, pp 483-506

Shiratake T, Sato A, Minoda A, Tsuzuki M, Sato N (2013) Air-drying of cells, the novel conditions for stimulated synthesis of triacylglycerol in a green alga, Chlorella kessleri. PLoS ONE. https://doi.org/10.1371/journal. pone.0079630

Show K-Y, Lee D-J, Tay J-H, Lee T-M, Chang J-S (2015) Microalgal drying and cell disruption-recent advances. Bioresour Technol 184:258-266. https:// doi.org/10.1016/j.biortech.2014.10.139

Simionato D, Block MA, Rocca NL, Jouhet J, Marechal E, Finazzi G, Morosinotto T (2013) the response of Nannochloropsis gaditana to nitrogen starvation includes de novo biosynthesis of triacylglycerols, a decrease of chloroplast galactolipids, and reorganization of the photosynthetic apparatus. Eukaryot Cell 12:665-676. https://doi.org/10.1128/ ec.00363-12

Sing SF, Isdepsky A, Borowitzka MA, Moheimani NR (2013) Production of biofuels from microalgae. Mitig Adapt Strateg Glob Change 18:47-72. https://doi.org/10.1007/s11027-011-9294-x

Singh P, Baranwal M, Reddy SM (2016) Antioxidant and cytotoxic activity of carotenes produced by Dunaliella salina under stress. Pharm Biol 54(10):22269-22275

Skjånes K, Rebours C, Lindblad P (2012) Potential for green microalgae to produce hydrogen, pharmaceuticals and other high value products in a combined process. Crit Rev Biotechnol 33:172-215. https://doi.org/10.3 109/07388551.2012.681625

Soratana K, Barr WJ, Landis AE (2014) Effects of co-products on the life-cycle impacts of microalgal biodiesel. Bioresour Technol 159:157-166. https:// doi.org/10.1016/j.biortech.2014.02.070

Soto Sierra L, Dixon CK, Wilken LR (2017) Enzymatic cell disruption of the microalgae Chlamydomonas reinhardtii for lipid and protein extraction. Algal Res 25:149-159. https://doi.org/10.1016/j.algal.2017.04.004 
Steriti A, Rossi R, Concas A, Cao G (2014) A novel cell disruption technique to enhance lipid extraction from microalgae. Bioresour Technol 164:70-77. https://doi.org/10.1016/j.biortech.2014.04.056

Swanson D, Block R, Mousa SA (2012) Omega-3 fatty acids EPA and DHA: health benefits throughout life. Adv Nutr 3:1-7. https://doi.org/10.3945/ an. 111.000893

Tan XB, Lam MK, Uemura Y et al (2018) Cultivation of microalgae for biodiesel production: a review on upstream and downstream processing. Chin J Chem Eng 26:17-30. https://doi.org/10.1016/j.cjche.2017.08.010

t'Lam G, Vermuë M, Eppink M et al (2018) Multi-product microalgae biorefineries: from concept towards reality. Trends Biotechnol 36:216-227. https://doi.org/10.1016/j.tibtech.2017.10.011

Tran M, Van C, Barrera DJ, Pettersson PL, Peinado CD, Bui J, Mayfield SP (2012) Production of unique immunotoxin cancer therapeutics in algal chloroplasts. Proc Natl Acad Sci USA 110:E15-E22. https://doi.org/10.1073/ pnas. 1214638110

Ummalyma SB, Pandey A, Sukumaran RK, Sahoo D (2018) Bioremediation by microalgae: current and emerging trends for effluents treatments for value addition of waste streams. In: Varjani S, Parameswaran B, Kumar S, Khare S (eds) Biosynthetic technology and environmental challenges. Energy, environment, and sustainability. Springer, Singapore, pp 355-375

Vandamme D (2013) Flocculation based harvesting processes for microalgae biomass production. Dissertation, KU Leuven

Vanthoor-Koopmans M, Wijffels RH, Barbosa MJ, Eppink MH (2013) Biorefinery of microalgae for food and fuel. Bioresour Technol 135:142-149. https:// doi.org/10.1016/j.biortech.2012.10.135

Vieler A, Brubaker SB, Vick B, Benning C (2012) A lipid droplet protein of Nannochloropsis with functions partially analogous to plant oleosins. Plant Physiol 158:1562-1569. https://doi.org/10.1104/pp.111.193029

Wan C, Alam MA, Zhao X-Q et al (2015) Current progress and future prospect of microalgal biomass harvest using various flocculation technologies. Bioresour Technol 184:251-257. https://doi.org/10.1016/j. biortech.2014.11.081

Wang K (2014) Bio-plastic potential of spirulina microalgae. Master's Thesis, University of Georgia

Wang M, Yuan W (2014) Bacterial lysis of microalgal cells. J Sustain Bioenergy Syst 4:243-248. https://doi.org/10.4236/jsbs.2014.44022

Wang ZT, Ullrich N, Joo S, Waffenschmidt S, Goodenough U (2009) Algal lipid bodies: stress induction, purification, and biochemical characterization in wild-type and starchless Chlamydomonas reinhardtii. Eukaryot Cell 8:1856-1868. https://doi.org/10.1128/ec.00272-09

Wang M, Yuan W, Jiang X, Jing Y, Wang Z (2014) Disruption of microalgal cells using high-frequency focused ultrasound. Bioresour Technol 153:315-321. https://doi.org/10.1016/j.biortech.2013.11.054

Wang H-MD, Chen C-C, Huynh P, Chang J-S (2015) Exploring the potential of using algae in cosmetics. Bioresour Technol 184:355-362. https://doi. org/10.1016/j.biortech.2014.12.001

Wilken LR, Nikolov ZL (2016) Aqueous fractionation of dry-milled corn germ for food protein production. In: Nedović V, Raspor P, Levié J, Tumbas Šaponjac V, Barbosa-Cánovas G (eds) Emerging and traditional technologies for safe, healthy and quality food. Springer, Cham, pp 443-464

Wu J-W, Chen X-L (2011) Extracellular metalloproteases from bacteria. Appl Microbiol Biotechnol 92:253-262. https://doi.org/10.1007/ s00253-011-3532-8

Wu X, Ruan R, Du Z, Liu Y (2012) Current status and prospects of biodiesel production from microalgae. Energies 5:2667-2682. https://doi. org/10.3390/en5082667

Wu C, Xiao Y, Lin W et al (2017) Aqueous enzymatic process for cell wall degradation and lipid extraction from Nannochloropsis sp. Bioresour Technol 223:312-316. https://doi.org/10.1016/j.biortech.2016.10.063

Yaakob Z, Ali E, Zainal A, Mohamad M, Takriff MS (2014) An overview: biomolecules from microalgae for animal feed and aquaculture. J Biol Res 21:6. https://doi.org/10.1186/2241-5793-21-6

Yan N, Fan C, Chen Y, Hu Z (2016) The potential for microalgae as bioreactors to produce pharmaceuticals. Int J Mol Sci 17:962. https://doi. org/10.3390/ijms17060962

Yap BH, Dumsday GJ, Scales PJ, Martin GJ (2015) Energy evaluation of algal cell disruption by high pressure homogenisation. Bioresour Technol 184:280-285. https://doi.org/10.1016/j.biortech.2014.11.049
Yoo G, Park W-K, Kim CW, Choi Y-E, Yang J-W (2012) Direct lipid extraction from wet Chlamydomonas reinhardtii biomass using osmotic shock. Bioresour Technol 123:717-722. https://doi.org/10.1016/j. biortech.2012.07.102

Yusibov V, Kushnir N, Streatfield SJ (2016) Antibody production in plants and green algae. Annu Rev Plant Biol 67:669-701. https://doi.org/10.1146/ annurev-arplant-043015-111812

Zbinden MDA, Sturm BS, Nord RD, Carey WJ, Moore D, Shinogle H, Stagg-Williams SM (2013) Pulsed electric field (PEF) as an intensification pretreatment for greener solvent lipid extraction from microalgae. Biotechnol Bioeng 110:1605-1615. https://doi.org/10.1002/bit.24829

Zderic A, Zondevan E, Meuldijk J (2013) Breakage of cellular tissue by pulsed electric field: extraction of polyphenols from fresh tea leaves. Chem Eng Trans 32:1795-1800. https://doi.org/10.3303/CET1332300

Zeller MA, Hunt R, Jones A, Sharma S (2013) Bioplastics and their thermoplastic blends from Spirulina and Chlorella microalgae. J Appl Polym Sci 130:3263-3275. https://doi.org/10.1002/app.39559

Zhang X, Yan S, Tyagi RD et al (2016) Energy balance of biofuel production from biological conversion of crude glycerol. J Environ Manag 170:169-176. https://doi.org/10.1016/j.jenvman.2015.09.031

Zheng H, Yin J, Gao Z, Huang H, Ji X, Dou C (2011) Disruption of Chlorella vulgaris cells for the release of biodiesel-producing lipids: a comparison of grinding, ultrasonication, bead milling, enzymatic lysis, and microwaves. Appl Biochem Biotechnol 164:1215-1224. https://doi. org/10.1007/s12010-011-9207-1

Zhu L (2015) Biorefinery as a promising approach to promote microalgae industry: an innovative framework. Renew Sustain Energy Rev 41:1376-1384. https://doi.org/10.1016/j.rser.2014.09.040

Zhu L, Nugroho Y, Shakeel S et al (2017) Using microalgae to produce liquid transportation biodiesel: what is next? Renew Sustain Energy Rev 78:391-400. https://doi.org/10.1016/j.rser.2017.04.089

Zuorro A, Lavecchiaa R, Maffeia G, Marraa F, Migliettab S, Petrangelia A, Familiarib G, Valentea T (2015) Enhanced lipid extraction from unbroken microalgal cells using enzymes. Chem Eng Trans 43:211-216. https:// doi.org/10.3303/CET1543036

Zuorro A, Miglietta S, Familiari G, Lavecchia R (2016) Enhanced lipid recovery from Nannochloropsis microalgae by treatment with optimized cell wall degrading enzyme mixtures. Bioresour Technol 212:35-41. https://doi. org/10.1016/j.biortech.2016.04.025

\section{Submit your manuscript to a SpringerOpen ${ }^{\odot}$ journal and benefit from:}

- Convenient online submission

- Rigorous peer review

- Open access: articles freely available online

- High visibility within the field

- Retaining the copyright to your article

Submit your next manuscript at $\boldsymbol{\nabla}$ springeropen.com 